This is a self-archived version of an original article. This version may differ from the original in pagination and typographic details.

Author(s): Kukkonen, Esa Petteri; Malinen, Henri; Haukka, Matti; Konu, Jari

Title: Reactivity of 4-Aminopyridine with Halogens and Interhalogens : Weak Interactions Supported Networks of 4-Aminopyridine and 4-Aminopyridinium

Year: 2019

Version: Accepted version (Final draft)

Copyright: @) 2019, American Chemical Society

Rights: CC BY 4.0

Rights url: https://creativecommons.org/licenses/by/4.0/

Please cite the original version:

Kukkonen, E. P., Malinen, H., Haukka, M., \& Konu, J. (2019). Reactivity of 4-Aminopyridine with Halogens and Interhalogens : Weak Interactions Supported Networks of 4-Aminopyridine and 4Aminopyridinium. Crystal Growth and Design, 19(4), 2434-2445.

https://doi.org/10.1021/acs.cgd.9b00119 


\title{
Reactivity of 4-Aminopyridine with Halogens and Interhalogens: Weak Interactions Supported Networks of 4-Aminopyridine and 4-Aminopyridinium
}

\author{
Esa Kukkonen, Henri Malinen, Matti Haukka, ${ }^{\circledR}$ and Jari Konu*º \\ Department of Chemistry, University vof Jyväskylä, P.O. Box 35, Jyväskylä FI-40014, Finland \\ Supporting Information
}

ABSTRACT: The reaction of 4-aminopyridine (4-AP) with $\mathrm{ICl}$ in a $1: 1$ molar ratio in $\mathrm{CH}_{2} \mathrm{Cl}_{2}$ produced the expected charge-transfer complex $\left[4-\mathrm{NH}_{2}-1 \lambda^{4}-\mathrm{C}_{5} \mathrm{H}_{4} \mathrm{~N}-1-\mathrm{ICl}\right](1 \cdot \mathrm{ICl})$ and the ionic species $\left[\left(4-\mathrm{NH}_{2}-1 \lambda^{4}-\mathrm{C}_{5} \mathrm{H}_{4} \mathrm{~N}\right)_{2}-1 \mu-\mathrm{I}^{+}\right]\left[\mathrm{Cl}^{-}\right](2$. $\left.\mathrm{Cl}^{-}\right)$in a $2: 1$ relation, as indicated by ${ }^{1} \mathrm{H}$ NMR spectroscopy in solution. In contrast, only the ionic compound [ $\left(4-\mathrm{NH}_{2}-\right.$ $\left.1 \lambda^{4}-\mathrm{C}_{5} \mathrm{H}_{4} \mathrm{~N}\right)_{2}-1 \mu$ - $\left.\mathrm{I}^{+}\right]\left[\mathrm{IBr}_{2}{ }^{-}\right]\left(2 \cdot \mathrm{IBr}_{2}{ }^{-}\right)$was observed in the analogous reaction with $\mathrm{IBr}$. The reaction between 4-AP and $\mathrm{I}_{2}$ in a 1:1 molar ratio also afforded two components, one of which was identified as the congeneric cation in $\left[\left(4-\mathrm{NH}_{2}-1 \lambda^{4}\right.\right.$ $\left.\left.\mathrm{C}_{5} \mathrm{H}_{4} \mathrm{~N}\right)_{2}-1 \mu-\mathrm{I}^{+}\right]\left[\mathrm{I}_{7}^{-}\right]\left(2 \cdot \mathrm{I}_{7}^{-}\right)$that contains a polyiodide anion as a result of transformation in a 1:2 molar ratio between the starting materials. In all of these ionic products, the crystal structures feature an iodonium ion, $\mathrm{I}^{+}$, trapped between two 4-AP rings through $\mathrm{N} \cdots \mathrm{I}^{+} \cdots \mathrm{N}$ contact. Surprisingly, the reaction of 4- $\mathrm{AP}$ with $\mathrm{Br}_{2}$ in $\mathrm{CH}_{2} \mathrm{Cl}_{2}$ resulted in an immediate protonation of the 4-aminopyridine $\left({ }^{1} \mathrm{H} \mathrm{NMR}\right)$ and $\left[4-\mathrm{NH}_{2}-1 \lambda^{4}-\mathrm{C}_{5} \mathrm{H}_{4} \mathrm{~N}-1\right.$ $\left.\mathrm{H}^{+}\right]\left[\mathrm{Br}^{-}\right]\left(3 \cdot \mathrm{Br}^{-}\right)$was characterized as the main product. A subsequent peculiar bromination-dimerization process afforded the novel pyridyl-pyridinium cations $\left\{3,3^{\prime}, 5^{\prime}-\mathrm{Br}_{3}-1 \lambda^{4}-\left[1,2^{\prime}-\left(\mathrm{C}_{5} \mathrm{H}_{4} \mathrm{~N}\right)_{2}\right]-4,4^{\prime}-\left(\mathrm{NH}_{2}\right)_{2}\right\}^{+}\left[\mathrm{X}^{-}\right]\left(4 \cdot \mathrm{Br}^{-}, 4 \cdot \mathrm{Br}_{3}^{-}\right)$and $\left\{3^{\prime}, 5^{\prime}-\mathrm{Br}_{2}-1 \lambda^{4}-\left[1,2^{\prime}-\right.\right.$ $\left.\left.\left(\mathrm{C}_{5} \mathrm{H}_{4} \mathrm{~N}\right)_{2}\right]-4,4^{\prime}-\left(\mathrm{NH}_{2}\right)_{2}\right\}^{+}\left[\mathrm{X}^{-}\right]\left(\mathbf{5} \cdot \mathrm{Br}^{-}, \mathbf{5} \cdot \mathrm{Br}_{3}^{-}\right)$. Compounds $\mathbf{1}-\mathbf{5}$ as well as two protonated species, $\left[4-\mathrm{NH}_{2}-1 \lambda^{4}-\mathrm{C}_{5} \mathrm{H}_{4} \mathrm{~N}-1-\right.$ $\left.\mathrm{H}^{+}\right]_{2}\left[\mathrm{Cl}^{-}\right]\left[\mathrm{I}_{3}^{-}\right]\left(3_{2} \cdot \mathrm{Cl}^{-} \cdot \mathrm{I}_{3}^{-}\right)$and $\left[\left(4-\mathrm{NH}_{2}-1 \lambda^{4}-\mathrm{C}_{5} \mathrm{H}_{4} \mathrm{~N}\right)_{2}-1 \mu-\mathrm{H}^{+}\right]\left[\mathrm{I}^{-}\right]\left(6 \cdot \mathrm{I}^{-}\right)$, all display extended 3D networks supported by halogen and hydrogen bonding in the solid state.

\section{INTRODUCTION}

The halogen bond $(\mathrm{XB})$ was first discovered in $1863,{ }^{1}$ some 50 years before its conceptual congener, the hydrogen bond. ${ }^{2}$ While the latter concept has drawn significantly more attention during the last century, the past few decades have also witnessed increasing interest toward both theoretical ${ }^{3-10}$ and practical aspects of $\mathrm{XB}$, especially through utilization of halogen bonds in building functional materials. ${ }^{1-19}$ Accordingly, numerous applications in a variety of fields such as ion recognition, ${ }^{20-26}$ optical materials, ${ }^{27-30}$ organic synthesis and catalysis, ${ }^{31}$ medicinal chemistry, ${ }^{32-37}$ and crystal engineering and supramolecular chemistry ${ }^{38-43}$ have been reported. It is evident that the halogen-bonding concept has grown from infancy to maturity. Owing to the versatility of adjustable properties, for example the directionality and strength of $\mathrm{XB}$, halogen bonding has the potential to become as widely used a chemical tool as hydrogen bonding.

IUPAC's recent definition for the halogen bond describes it as an interaction between an electrophilic region of a polarized halogen atom (XB donor) and a nucleophilic region of another, or the same, molecular entity (XB acceptor). ${ }^{44}$ Effectively this means that, somewhat counterintuitively, the $\mathrm{XB}$ donor (halogen atom) acts as the $\mathrm{e}^{-}$acceptor and the $\mathrm{XB}$ acceptor is the $\mathrm{e}^{-}$donor. Although the $\mathrm{XB}$ interaction is often considered to be primarily electrostatic in nature, the definition includes virtually all noncovalent electron donor-acceptor connections involving halogen atoms: for example, chargetransfer contacts and dispersion forces. Molecular properties of the $\mathrm{XB}$ components (electron delocalization, exchange repulsion, polarization, etc. of the $\mathrm{XB}$ donors and acceptors) are also contributing factors to the nature of halogen bonds. ${ }^{7,45,46}$ Similarly to the perfluorohalocarbons, another widely used group of halogen compounds, ${ }^{47}$ dihalogens $\left(\mathrm{X}_{2}\right)$ can act as halogen bond donors. In the case of $\mathrm{X}_{2}$, the formation of a halogen bond is often understood as a chargetransfer process in which the $\mathrm{XB}$ acceptor donates electron density to the $\sigma^{*}$ orbital of the $\mathrm{X}_{2}$ molecule, providing the attractive electrostatic interaction between the $\mathrm{XB}$ components. At the very least the $\mathrm{XB}$ contact results in polarization and weakening in the $\mathrm{X}-\mathrm{X}$ bond of dihalogen, but even heterolytic cleavage with the formation of ion pairs $\left(\mathrm{X}^{+} / \mathrm{X}^{-}\right.$ containing units) is commonly observed. Stabilization of the consequent halonium cation $\left(\mathrm{X}^{+}\right)$typically requires the presence of two (or more) $\mathrm{XB}$ acceptors such as in the

Received: January 25, 2019

Revised: March 4, 2019

Published: March 8, 2019 
Scheme 1. Reactions of 4-Aminopyridine (4-AP) with $\mathrm{ICl}, \mathrm{IBr}, \mathrm{Br}_{2}$, and $\mathrm{I}_{2}$ in $\mathrm{CH}_{2} \mathrm{Cl}_{2}$<smiles></smiles><smiles>CC(C)[C@@H]1C=C[N+]([I-])([I-])CC1</smiles><smiles></smiles><smiles>CC(Cl)(Cl)c1cnccc1N</smiles><smiles>CC(N)=CBr</smiles><smiles>CC(C)(C)Nc1ccccc1</smiles><smiles>CCC(C)[n+]1ccc([N+](=O)[O-])cc1</smiles>

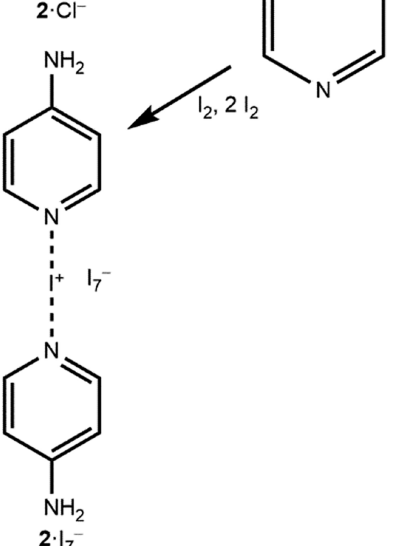

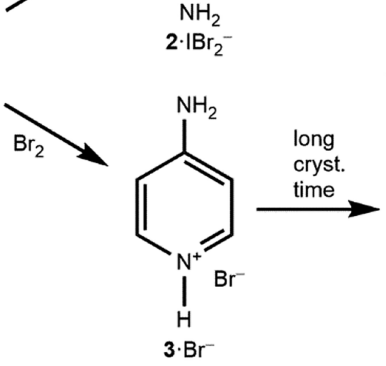<smiles></smiles>

classical example of iodonium cation trapped between two pyridine nitrogen donors through $\mathrm{N} \cdots \mathrm{I}^{+} \cdots \mathrm{N}$ contacts. ${ }^{48}$ Recent studies suggest that the $\mathrm{N} \cdots \mathrm{X}^{+} \cdots \mathrm{N}$ arrangement is comprised of a three-center-four-electron bond ${ }^{49}$ that also can be utilized as useful XB donors. ${ }^{38-43}$

Halogen-bonded systems with $\mathrm{X}_{2}$ molecules and charge distribution in $\mathrm{X}_{2}$ and polyhalides have been extensively investigated. ${ }^{50-57}$ However, to our knowledge systematic studies of the effect of charge distribution in dihalogens on the formation of halogen bonds are virtually nonexistent. ${ }^{58}$ In this connection, we describe here our investigations of the reactions between 4-aminopyridine (4-AP) and heavier halogens and interhalogens, namely $\mathrm{ICl}, \mathrm{IBr}, \mathrm{Br}_{2}$, and $\mathrm{I}_{2}$, conducted in $\mathrm{CH}_{2} \mathrm{Cl}_{2}$. The reactions were monitored by ${ }^{1} \mathrm{H}$ NMR spectroscopy in solution, and the formation (Scheme 1) and single-crystal $\mathrm{X}$-ray structures of $\left[4-\mathrm{NH}_{2}-1 \lambda^{4}-\mathrm{C}_{5} \mathrm{H}_{4} \mathrm{~N}-1\right.$ $\mathrm{ICl}](\mathbf{1} \cdot \mathrm{ICl}),\left[\left(4-\mathrm{NH}_{2}-1 \lambda^{4}-\mathrm{C}_{5} \mathrm{H}_{4} \mathrm{~N}\right)_{2}-1 \mu-\mathrm{I}^{+}\right]\left[\mathrm{Cl}^{-}\right]\left(2 \cdot \mathrm{Cl}^{-}\right),[(4-$ $\left.\left.\mathrm{NH}_{2}-1 \lambda^{4}-\mathrm{C}_{5} \mathrm{H}_{4} \mathrm{~N}\right)_{2}-1 \mu-\mathrm{I}^{+}\right]\left[\mathrm{IBr}_{2}{ }^{-}\right]\left(2 \cdot \mathrm{IBr}_{2}{ }^{-}\right), \quad\left[\left(4-\mathrm{NH}_{2}-1 \lambda^{4}-\right.\right.$ $\left.\left.\mathrm{C}_{5} \mathrm{H}_{4} \mathrm{~N}\right)_{2}-1 \mu-\mathrm{I}^{+}\right]\left[\mathrm{I}_{7}^{-}\right]\left(2 \cdot \mathrm{I}_{7}^{-}\right),\left[4-\mathrm{NH}_{2}-1 \lambda^{4}-\mathrm{C}_{5} \mathrm{H}_{4} \mathrm{~N}-1-\mathrm{H}^{+}\right]\left[\mathrm{Br}^{-}\right]$ $\left(3 \cdot \mathrm{Br}^{-}\right), \quad\left[4-\mathrm{NH}_{2}-1 \lambda^{4}-\mathrm{C}_{5} \mathrm{H}_{4} \mathrm{~N}-1-\mathrm{H}^{+}\right]_{2}\left[\mathrm{Cl}^{-}\right]\left[\mathrm{I}_{3}{ }^{-}\right] \quad\left(3_{2} \cdot \mathrm{Cl}^{-} \cdot \mathrm{I}_{3}{ }^{-}\right)$, $\left\{3,3^{\prime}, 5^{\prime}-\mathrm{Br}_{3}-1 \lambda^{4}-\left[1,2^{\prime}-\left(\mathrm{C}_{5} \mathrm{H}_{4} \mathrm{~N}\right)_{2}\right]-4,4^{\prime}-\left(\mathrm{NH}_{2}\right)_{2}\right\}^{+}\left[\mathrm{X}^{-}\right] \quad\left(4 \cdot \mathrm{Br}^{-}\right.$, $\left.4 \cdot \mathrm{Br}_{3}{ }^{-}\right)$and $\left\{3^{\prime}, 5^{\prime}-\mathrm{Br}_{2}-1 \lambda^{4}-\left[1,2^{\prime}-\left(\mathrm{C}_{5} \mathrm{H}_{4} \mathrm{~N}\right)_{2}\right]-4,4^{\prime}-\right.$ $\left.\left(\mathrm{NH}_{2}\right)_{2}\right\}^{+}\left[\mathrm{X}^{-}\right]\left(5 \cdot \mathrm{Br}^{-}, \mathbf{5} \cdot \mathrm{Br}_{3}^{-}\right)$and $\left[\left(4-\mathrm{NH}_{2}-1 \lambda^{4}-\mathrm{C}_{5} \mathrm{H}_{4} \mathrm{~N}\right)_{2}-\right.$ $\left.1 \mu-\mathrm{H}^{+}\right]\left[\mathrm{I}^{-}\right]\left(6 \cdot \mathrm{I}^{-}\right)$, as well as the main features of the halogenand hydrogen-bonding-supported extended 3D networks, are discussed.

\section{EXPERIMENTAL METHODS}

Reagents and General Procedures. The reactions were carried out in air. All of the starting materials and solvents were purchased from commercial sources. Solvents were dried over $3 \AA$ molecular sieves, and the remaining reagents were used without further purification: 4-aminopyridine (Aldrich, 98\%), iodine monochloride
(Aldrich, 98\%), iodine monobromide (Aldrich, 98\%), iodine (Merck, 99.999\%), bromine (Fluka, >99\%), MeCN (VWR Chemicals, 99.9\%), $\mathrm{Et}_{2} \mathrm{O}$ (Aldrich, >99.8\%), $\mathrm{CH}_{2} \mathrm{Cl}_{2}$ (VWR Chemicals, 99\%), hexanes (VWR Chemicals, 99\%), THF (Aldrich, >99.9\%), and toluene (Aldrich, >99.5\%). Elemental analyses were performed by analytical services at the Department of Chemistry, University of Jyväskylä.

Spectroscopic Methods. The ${ }^{1} \mathrm{H}$ NMR spectra were obtained in $\mathrm{CD}_{3} \mathrm{CN}$ at $30{ }^{\circ} \mathrm{C}$ and at $-20{ }^{\circ} \mathrm{C}$ ( $\mathrm{ICl}$ and $\mathrm{IBr}$ reactions only) on Bruker Avance III 300 and Bruker Avance III 500 spectrometers operating at 300.15 and $500.13 \mathrm{MHz}$, respectively. ${ }^{1} \mathrm{H}$ NMR spectra are referenced to the solvent signal, and the chemical shifts are reported relative to $\left(\mathrm{CH}_{3}\right)_{4} \mathrm{Si}$.

X-ray Crystallography. Crystallographic data for compounds $\mathbf{1}$. $\mathrm{ICl}$ and $2 \cdot \mathrm{Cl}^{-}, 2 \cdot \mathrm{Cl}^{-}, 2 \cdot \mathrm{IBr}_{2}^{-} \cdot$ mono, $2 \cdot \mathrm{IBr}_{2}{ }^{-}$ortho, $3_{2} \cdot \mathrm{Cl}^{-} \cdot \mathrm{I}_{3}{ }^{-}, 3 \cdot \mathrm{Br}^{-}$. $\mathrm{CH}_{2} \mathrm{Cl}_{2}, 4 \cdot \mathrm{Br}^{-}, 4 \cdot \mathrm{Br}_{3}{ }^{-}, \mathbf{5} \cdot \mathrm{Br}^{-}, 5 \cdot \mathrm{Br}_{3}{ }^{-}, 2 \cdot \mathrm{I}_{7}^{-}$, and $6 \cdot \mathrm{I}^{-}$are summarized in Tables $\mathrm{S} 1$ and $\mathrm{S} 2$ in the Supporting Information. Crystals were coated with FomblinY oil and mounted on a MiTeGen loop. Diffraction data were collected on an Agilent SuperNova Dual Source diffractometer equipped with Atlas $\mathrm{CCD}$ area detector using graphitemonochromatized $\mathrm{Cu} \mathrm{K} \alpha$ radiation $\left(\lambda=1.54184 \AA ; 1 \cdot \mathrm{ICl}\right.$ and $2 \cdot \mathrm{Cl}^{-}$, $3_{2} \cdot \mathrm{Cl}^{-} \cdot \mathrm{I}_{3}{ }^{-}, 2 \cdot \mathrm{IBr}_{2}{ }^{-} \cdot$ mono, $2 \cdot \mathrm{IBr}_{2}{ }^{-}$ortho, $3 \cdot \mathrm{Br}^{-} \cdot \mathrm{CH}_{2} \mathrm{Cl}_{2}, 4 \cdot \mathrm{Br}^{-}, 4 \cdot \mathrm{Br}_{3}{ }^{-}$, $5 \cdot \mathrm{Br}^{-}, 5 \cdot \mathrm{Br}_{3}^{-}$, and $\left.6 \cdot \mathrm{I}^{-}\right)$or Mo K $\alpha$ radiation $\left(\lambda=0.71073 \AA ; 2 \cdot \mathrm{Cl}^{-}\right.$ and $\left.2 \cdot \mathrm{I}_{7}^{-}\right)$at $-150{ }^{\circ} \mathrm{C}$. The data were processed by applying Gaussian absorption correction for compounds $2 \cdot \mathrm{Cl}^{-}, \mathbf{2} \cdot \mathrm{IBr}_{2}^{-}$.ortho, and $\mathbf{6} \cdot \mathrm{I}^{-}$ and by performing analytical numeric absorption correction for compounds $1 \cdot \mathrm{ICl}$ and $2 \cdot \mathrm{Cl}^{-}, 3_{2} \cdot \mathrm{Cl}^{-} \cdot \mathrm{I}_{3}^{-}, 2 \cdot \mathrm{IBr}_{2}^{-} \cdot \mathrm{mono}, 4 \cdot \mathrm{Br}^{-}, 4 \cdot \mathrm{Br}_{3}^{-}$, $5 \cdot \mathrm{Br}^{-}, 5 \cdot \mathrm{Br}_{3}^{-}$, and $2 \cdot \mathrm{I}_{7}^{-}$using a multifaceted crystal with the CrysAlisPro program. ${ }^{59}$ All structures were solved by direct methods with SHELXS or SHELXT and refined by using SHELXL implemented in the Olex ${ }^{2}$ program package. ${ }^{60,61}$ After full-matrix least-squares refinement of the non-hydrogen atoms with anisotropic thermal parameters, the carbon-bound hydrogen atoms were placed in calculated positions $(\mathrm{C}-\mathrm{H}=0.93 \AA$ ). The nitrogen-bonded $\mathrm{H}$ atoms were located from the difference Fourier map for compounds $1 \cdot \mathrm{ICl}$ and $2 \cdot \mathrm{Cl}^{-}, 2 \cdot \mathrm{Cl}^{-}, 2 \cdot \mathrm{IBr}_{2}^{-} \cdot$ mono, $2 \cdot \mathrm{IBr}_{2}^{-} \cdot$ ortho, $4 \cdot \mathrm{Br}^{-}, 5 \cdot \mathrm{Br}_{3}{ }^{-}, 2 \cdot \mathrm{I}_{7}^{-}$, and $6 \cdot \mathrm{I}^{-}$, while for compounds $3{ }_{2} \cdot \mathrm{Cl}^{-} \cdot \mathrm{I}_{3}{ }^{-}, 4 \cdot \mathrm{Br}_{3}{ }^{-}$, and $5 \cdot \mathrm{Br}^{-}$the $-\mathrm{NH}_{2}$ hydrogens were calculated $(\mathrm{N}-\mathrm{H}=0.86 \AA)$. The isotropic 
thermal parameters of the calculated hydrogen atoms were fixed at 1.2 times that of the corresponding carbon or nitrogen. In the final refinement, the calculated hydrogen atoms were riding on their respective carbon or nitrogen atoms, and the $-\mathrm{NH}_{2}$ hydrogens located in the difference Fourier map were refined as isotropic with case-specific restrictions in the $\mathrm{N}-\mathrm{H}$ bond distances.

Reaction of 4-AP with ICl in 1:1 Molar Ratio. A solution of $\mathrm{ICl}$ $(0.162 \mathrm{~g}, 1.00 \mathrm{mmol})$ in $10 \mathrm{~mL}$ of $\mathrm{CH}_{2} \mathrm{Cl}_{2}$ was added dropwise to a solution of 4-AP $(0.094 \mathrm{~g}, 1.00 \mathrm{mmol})$ in $10 \mathrm{~mL}$ of $\mathrm{CH}_{2} \mathrm{Cl}_{2}$ at $23{ }^{\circ} \mathrm{C}$. The reaction mixture was stirred for $2 \mathrm{~h}$, giving a red solution and a pale red precipitate. The solvent was decanted, and the solid product was dried under vacuum to afford $0.115 \mathrm{~g}$ of a red powder $(45 \%$, calculated as an equimolar mixture of the starting materials). The solvent portion was evaporated and dried under vacuum, giving a brown powder $(0.051 \mathrm{~g})$ that was shown by ${ }^{1} \mathrm{H}$ NMR spectroscopy to contain primarily only one of the products observed in the initial powder $\left({ }^{1} \mathrm{H}\right.$ NMR of the solvent portion $\left(\mathrm{CD}_{3} \mathrm{CN}, 30{ }^{\circ} \mathrm{C}\right): \delta 8.04$ $\left[\mathrm{m}, 2 \mathrm{H},-\mathrm{C}_{5} \mathrm{H}_{4} \mathrm{~N}\right], \delta 6.56\left[\mathrm{~m}, 2 \mathrm{H},-\mathrm{C}_{5} \mathrm{H}_{4} \mathrm{~N}\right], \delta 5.76[\mathrm{~s}, \mathrm{br}, 2 \mathrm{H}$, $\left.-\mathrm{NH}_{2}\right]$ ). Anal. Calcd for $\mathrm{C}_{20} \mathrm{H}_{24} \mathrm{~N}_{8} \mathrm{Cl}_{3} \mathrm{I}_{3}$ (calculated as a $2: 1$ mixture of $\left[4-\mathrm{NH}_{2}-1 \lambda^{4}-\mathrm{C}_{5} \mathrm{H}_{4} \mathrm{~N}-1-\mathrm{ICl}\right](\mathbf{1} \cdot \mathrm{ICl})$ and $\left[\left(4-\mathrm{NH}_{2}-1 \lambda^{4}-\mathrm{C}_{5} \mathrm{H}_{4} \mathrm{~N}\right)_{2}-1 \mu\right.$ $\left.\left.\mathrm{I}^{+}\right]\left[\mathrm{Cl}^{-}\right]\left(2 \cdot \mathrm{Cl}^{-}\right)\right): \mathrm{C}, 27.82 ; \mathrm{H}, 2.80 ; \mathrm{N}, 12.98$. Found: C, 27.64; $\mathrm{H}$, 2.83 ; N, 13.10. ${ }^{1} \mathrm{H}$ NMR of the initial powder $\left(\mathrm{CD}_{3} \mathrm{CN}, 30{ }^{\circ} \mathrm{C}\right): \delta$ $8.06\left[\mathrm{~m}, 4 \mathrm{H},-\mathrm{C}_{5} \mathrm{H}_{4} \mathrm{~N}\right], \delta 6.58\left[\mathrm{~m}, 4 \mathrm{H},-\mathrm{C}_{5} \mathrm{H}_{4} \mathrm{~N}\right], \delta 5.72[\mathrm{~s}, \mathrm{br}, 2 \mathrm{H}$, $\left.-\mathrm{NH}_{2}\right], \delta 5.32\left[\mathrm{~s}, \mathrm{br}, 2 \mathrm{H},-\mathrm{NH}_{2}\right] .{ }^{1} \mathrm{H}$ NMR of the initial powder $\left(\mathrm{CD}_{3} \mathrm{CN},-20{ }^{\circ} \mathrm{C}\right): \delta 8.06\left[\mathrm{~m}, 2 \mathrm{H},-\mathrm{C}_{5} \mathrm{H}_{4} \mathrm{~N}\right], \delta 7.98[\mathrm{~m}, 2 \mathrm{H}$, $\left.-\mathrm{C}_{5} \mathrm{H}_{4} \mathrm{~N}\right], \delta 6.61\left[\mathrm{~m}, 2 \mathrm{H},-\mathrm{C}_{5} \mathrm{H}_{4} \mathrm{~N}\right], \delta 6.52\left[\mathrm{~m}, 2 \mathrm{H},-\mathrm{C}_{5} \mathrm{H}_{4} \mathrm{~N}\right], \delta$ $5.88\left[\mathrm{~s}, \mathrm{br}, 2 \mathrm{H},-\mathrm{NH}_{2}\right], \delta 5.53\left[\mathrm{~s}, \mathrm{br}, 2 \mathrm{H},-\mathrm{NH}_{2}\right]$. X-ray-quality crystals of cocrystalline $\left[4-\mathrm{NH}_{2}-1 \lambda^{4}-\mathrm{C}_{5} \mathrm{H}_{4} \mathrm{~N}-1-\mathrm{ICl}\right](\mathbf{1} \cdot \mathrm{ICl})$ and $[(4-$ $\left.\left.\mathrm{NH}_{2}-1 \lambda^{4}-\mathrm{C}_{5} \mathrm{H}_{4} \mathrm{~N}\right)_{2}-1 \mu-\mathrm{I}^{+}\right]\left[\mathrm{Cl}^{-}\right]\left(2 \cdot \mathrm{Cl}^{-}\right)$in a $1: 1$ molar ratio were obtained by slow evaporation of an $\mathrm{MeCN}$ solution at $23^{\circ} \mathrm{C}$. The crystals containing solely $\left[\left(4-\mathrm{NH}_{2}-1 \lambda^{4}-\mathrm{C}_{5} \mathrm{H}_{4} \mathrm{~N}\right)_{2}-1 \mu-\mathrm{I}^{+}\right]\left[\mathrm{Cl}^{-}\right]\left(2 \cdot \mathrm{Cl}^{-}\right)$ were grown by diffusion from an $\mathrm{MeCN}$ solution layered with $\mathrm{Et}_{2} \mathrm{O}$. Extended crystallization time afforded protonation of the 4-aminopyridine; the crystals of $\left[\left(4-\mathrm{NH}_{2}-1 \lambda^{4}-\mathrm{C}_{5} \mathrm{H}_{4} \mathrm{~N}-1-\mathrm{H}\right)^{+}\right]_{2}\left[\mathrm{Cl}^{-}\right]\left[\mathrm{I}_{3}^{-}\right]\left(3_{2}\right.$. $\left.\mathrm{Cl}^{-} \cdot \mathrm{I}_{3}{ }^{-}\right)$were obtained by evaporation of a toluene solution at $23^{\circ} \mathrm{C}$.

Reaction of 4-AP with IBr in 1:1 Molar Ratio. A solution of $\mathrm{IBr}$ $(0.207 \mathrm{~g}, 1.00 \mathrm{mmol})$ in $10 \mathrm{~mL}$ of $\mathrm{CH}_{2} \mathrm{Cl}_{2}$ was added dropwise to a solution of 4-AP $(0.094 \mathrm{~g}, 1.00 \mathrm{mmol})$ in $5 \mathrm{~mL}$ of $\mathrm{CH}_{2} \mathrm{Cl}_{2}$ at $23{ }^{\circ} \mathrm{C}$. The resulting orange reaction mixture was stirred for $2 \mathrm{~h}$. The solvent was decanted, and the solid product was dried under vacuum to afford a pale orange powder. The solvent portion was allowed to evaporate under ambient conditions over a period of 3 days, giving an orange powder that was shown by NMR spectroscopy to be identical with that of the solution portion (combined yield $0.237 \mathrm{~g}, 79 \%$, calculated as an equimolar mixture of the starting materials). Anal. Calcd for $\mathrm{C}_{5} \mathrm{H}_{6} \mathrm{~N}_{2}$ BrI: C, 19.96; H, 2.01; N, 9.31. Found: C, 19.91; H, 2.13; N, 9.40. ${ }^{1} \mathrm{H}$ NMR $\left(\mathrm{CD}_{3} \mathrm{CN}, 30^{\circ} \mathrm{C}\right): \delta 8.05\left[\mathrm{~s}, \mathrm{br}, 2 \mathrm{H},-\mathrm{C}_{5} \mathrm{H}_{4} \mathrm{~N}\right], \delta 6.57$ $\left[\mathrm{s}, \mathrm{br}, 2 \mathrm{H},-\mathrm{C}_{5} \mathrm{H}_{4} \mathrm{~N}\right], \delta 5.83\left[\mathrm{~s}, \mathrm{br}, 1 \mathrm{H},-\mathrm{NH}_{2}\right], \delta 5.70[\mathrm{~s}, \mathrm{br}, 1 \mathrm{H}$, $\left.-\mathrm{NH}_{2}\right] .{ }^{1} \mathrm{H}$ NMR $\left(\mathrm{CD}_{3} \mathrm{CN},-20{ }^{\circ} \mathrm{C}\right): \delta 8.03\left[\mathrm{~m}, 2 \mathrm{H},-\mathrm{C}_{5} \mathrm{H}_{4} \mathrm{~N}\right], \delta$ $6.54\left[\mathrm{~m}, 2 \mathrm{H},-\mathrm{C}_{5} \mathrm{H}_{4} \mathrm{~N}\right], \delta 5.93\left[\mathrm{~s}, \mathrm{br}, 1 \mathrm{H},-\mathrm{NH}_{2}\right], \delta 5.83[\mathrm{~s}, \mathrm{br}, 1 \mathrm{H}$, $-\mathrm{NH}_{2}$ ]. X-ray-quality crystals of two polymorphs of [(4- $\mathrm{NH}_{2}-1 \lambda^{4}-$ $\left.\left.\mathrm{C}_{5} \mathrm{H}_{4} \mathrm{~N}\right)_{2}-1 \mu-\mathrm{I}^{+}\right]\left[\mathrm{IBr}_{2}^{-}\right]\left(2 \cdot \mathrm{IBr}_{2}^{-}\right)$(monoclinic and orthorhombic; 2 . $\mathrm{IBr}_{2}{ }^{-} \cdot$ mono, $2 \cdot \mathrm{IBr}_{2}{ }^{-} \cdot$ ortho) were both obtained by slow evaporation of a $\mathrm{CH}_{2} \mathrm{Cl}_{2}$ solution at $23{ }^{\circ} \mathrm{C}$.

Reaction of 4-AP with $\mathrm{Br}_{2}$ in 1:1 Molar Ratio. A solution of $\mathrm{Br}_{2}$ $(0.052 \mathrm{~mL}, 0.160 \mathrm{~g}, 1.00 \mathrm{mmol})$ in $5 \mathrm{~mL}$ of $\mathrm{CH}_{2} \mathrm{Cl}_{2}$ was added dropwise to a solution of 4-AP $(0.094 \mathrm{~g}, 1.00 \mathrm{mmol})$ in $5 \mathrm{~mL}$ of $\mathrm{CH}_{2} \mathrm{Cl}_{2}$ at $23{ }^{\circ} \mathrm{C}$. The reaction mixture was stirred for $2 \mathrm{~h}$, giving an orange solution and a yellow precipitate. The solvent was decanted, and the solid product was dried under vacuum to afford an orangeyellow powder $(0.187 \mathrm{~g}, 74 \%$, calculated as a $1: 1$ adduct of the starting materials). Anal. Calcd for $\mathrm{C}_{20} \mathrm{H}_{28} \mathrm{~N}_{8} \mathrm{Br}_{10}$ : C, 20.37; H, 2.39; N, 9.50. Found: C, 19.99; H, 2.21; N, 9.67. ${ }^{1} \mathrm{H}$ NMR $\left(\mathrm{CD}_{3} \mathrm{CN}, 30{ }^{\circ} \mathrm{C}\right): \delta$ $11.29\left[\mathrm{~m}, \mathrm{br}, 1 \mathrm{H}, \mathrm{C}_{5} \mathrm{H}_{4} \mathrm{NH}^{+}\right], \delta 7.94\left[\mathrm{~m}, 2 \mathrm{H}, \mathrm{C}_{5} \mathrm{H}_{4} \mathrm{NH}^{+}\right], \delta 6.85[\mathrm{~m}$, $\left.2 \mathrm{H}, \mathrm{C}_{5} \mathrm{H}_{4} \mathrm{NH}^{+}\right], \delta 6.60\left[\mathrm{~s}, \mathrm{br}, 2 \mathrm{H},-\mathrm{NH}_{2}\right.$ ]. X-ray-quality crystals of the initial main product, $\left[4-\mathrm{NH}_{2}-1 \lambda^{4}-\mathrm{C}_{5} \mathrm{H}_{4} \mathrm{~N}-1-\mathrm{H}^{+}\right]\left[\mathrm{Br}^{-}\right]\left(3 \cdot \mathrm{Br}^{-}\right)$, were obtained by slow diffusion from THF solution layered with $\mathrm{CH}_{2} \mathrm{Cl}_{2}$ at $23{ }^{\circ} \mathrm{C}$. Longer crystallization times resulted in the formation of brominated pyridyl-pyridinium cations: tribromides $\left\{3,3^{\prime}, 5^{\prime}-\mathrm{Br}_{3}-1 \lambda^{4}\right.$ $\left.\left[1,2^{\prime}-\left(\mathrm{C}_{5} \mathrm{H}_{4} \mathrm{~N}\right)_{2}\right]-4,4^{\prime}-\left(\mathrm{NH}_{2}\right)_{2}\right\}^{+}\left[\mathrm{X}^{-}\right]\left(4 \cdot \mathrm{Br}^{-}, 4 \cdot \mathrm{Br}_{3}^{-}\right)$by slow evapo- ration of $\mathrm{MeCN}\left(4 \cdot \mathrm{Br}^{-}\right)$and $\mathrm{CH}_{2} \mathrm{Cl}_{2}\left(4 \cdot \mathrm{Br}_{3}^{-}\right)$solutions and dibromides $\left\{3^{\prime}, 5^{\prime}-\mathrm{Br}_{2}-1 \lambda^{4}-\left[1,2^{\prime}-\left(\mathrm{C}_{5} \mathrm{H}_{4} \mathrm{~N}\right)_{2}\right]-4,4^{\prime}-\left(\mathrm{NH}_{2}\right)_{2}\right\}^{+}\left[\mathrm{X}^{-}\right] \quad$ (5. $\left.\mathrm{Br}^{-}, \mathbf{5} \cdot \mathrm{Br}_{3}{ }^{-}\right)$by slow diffusion from an MeCN solution layered with $\mathrm{Et}_{2} \mathrm{O}\left(5 \cdot \mathrm{Br}^{-}\right)$and a $\mathrm{CH}_{2} \mathrm{Cl}_{2}$ solution layered with hexanes $\left(5 \cdot \mathrm{Br}_{3}{ }^{-}\right)$at $23{ }^{\circ} \mathrm{C}$.

Reaction of 4-AP with $\mathrm{I}_{2}$ in 1:1 Molar Ratio. A solution of $\mathrm{I}_{2}$ $(0.254 \mathrm{~g}, 1.00 \mathrm{mmol})$ in $10 \mathrm{~mL}$ of $\mathrm{CH}_{2} \mathrm{Cl}_{2}$ was added dropwise to a solution of 4-AP $(0.094 \mathrm{~g}, 1.00 \mathrm{mmol})$ in $5 \mathrm{~mL}$ of $\mathrm{CH}_{2} \mathrm{Cl}_{2}$ at $23{ }^{\circ} \mathrm{C}$. The reaction mixture was stirred for $2 \mathrm{~h}$, giving a brownish yellow solution and a brown precipitate. The solvent was decanted, and the product was dried under vacuum to afford a brown powder $(0.215 \mathrm{~g}$, $62 \%$, calculated as a $1: 1$ adduct of the starting materials). Anal. Calcd for $\mathrm{C}_{5} \mathrm{H}_{6} \mathrm{~N}_{2} \mathrm{I}_{2}: \mathrm{C}, 17.26 ; \mathrm{H}, 1.74 ; \mathrm{N}, 8.05$. Found: $\mathrm{C}, 17.03 ; \mathrm{H}, 1.86$; $\mathrm{N}, 8.07 .{ }^{1} \mathrm{H}$ NMR $\left(\mathrm{CD}_{3} \mathrm{CN}, 30{ }^{\circ} \mathrm{C}\right): \delta 8.05\left[\mathrm{~m}, 2 \mathrm{H}, \mathrm{C}_{5} \mathrm{H}_{4} \mathrm{~N}\right], 8.01$ $\left[\mathrm{m}, 2 \mathrm{H}, \mathrm{C}_{5} \mathrm{H}_{4} \mathrm{~N}\right], \delta 6.57\left[\mathrm{~m}, 4 \mathrm{H}, \mathrm{C}_{5} \mathrm{H}_{4} \mathrm{~N}\right], \delta 5.83\left[\mathrm{~s}, \mathrm{br}, 2 \mathrm{H},-\mathrm{NH}_{2}\right], \delta$ $5.51\left[\mathrm{~s}, \mathrm{br}, 2 \mathrm{H},-\mathrm{NH}_{2}\right]$. Prolonged crystallization times resulted in the formation of protonated 4-aminopyridines that were not detectable in the initial product $\left({ }^{1} \mathrm{H} \mathrm{NMR}\right)$. X-ray-quality crystals of $\left[\left(4-\mathrm{NH}_{2}-1 \lambda^{4}\right.\right.$ $\left.\left.\mathrm{C}_{5} \mathrm{H}_{4} \mathrm{~N}\right)_{2}-1 \mu-\mathrm{H}^{+}\right]\left[\mathrm{I}^{-}\right]\left(6 \cdot \mathrm{I}^{-}\right)$were obtained by slow evaporation (ca. 8 days) of a $\mathrm{CH}_{2} \mathrm{Cl}_{2}$ solution at $23{ }^{\circ} \mathrm{C}$. Also, crystals of the previously determined salt of the 4-aminopyridinium species [4- $\mathrm{NH}_{2}-1 \lambda^{4}$ $\left.\mathrm{C}_{5} \mathrm{H}_{4} \mathrm{~N}-1-\mathrm{H}^{+}\right]_{2}\left[\mathrm{I}^{-}\right]\left[\mathrm{I}_{3}^{-}\right]\left(3_{2} \cdot \mathrm{I}^{-} \cdot \mathrm{I}_{3}^{-}\right.$; structure code WULTEE in the CSD database $)^{62}$ were detected on the basis of the unit cell measurements.

Reaction of 4-AP with $I_{2}$ in 1:2 Molar Ratio. Due to the apparent two products from the reaction of $4-\mathrm{AP}$ and $\mathrm{I}_{2}$ in a $1: 1$ molar ratio (as indicated by NMR spectroscopy), the reaction was repeated in a 1:2 molar ratio. A solution of 4-AP $(0.047 \mathrm{~g}, 0.50 \mathrm{mmol})$ in 10 $\mathrm{mL}$ of $\mathrm{CH}_{2} \mathrm{Cl}_{2}$ was added dropwise to a solution of $\mathrm{I}_{2}(0.254 \mathrm{~g}, 1.00$ $\mathrm{mmol}$ ) in $10 \mathrm{~mL}$ of $\mathrm{CH}_{2} \mathrm{Cl}_{2}$ at $23{ }^{\circ} \mathrm{C}$. The reaction mixture was stirred for $2 \mathrm{~h}$, giving a red solution and a dark brown precipitate. Solvent was evaporated under vacuum to afford a dark red powder (0.263 g, 87\%). Anal. Calcd for $\mathrm{C}_{5} \mathrm{H}_{6} \mathrm{~N}_{2} \mathrm{I}_{4}: \mathrm{C}, 9.98 ; \mathrm{H}, 1.01 ; \mathrm{N}, 4.66$. Found: $\mathrm{C}, 10.72 ; \mathrm{H}, 1.32 ; \mathrm{N}, 4.98 .{ }^{1} \mathrm{H}$ NMR $\left(\mathrm{CD}_{3} \mathrm{CN}, 30^{\circ} \mathrm{C}\right): \delta 8.04$ $\left[\mathrm{m}, 2 \mathrm{H}, \mathrm{C}_{5} \mathrm{H}_{4} \mathrm{~N}\right], 6.59\left[\mathrm{~m}, 2 \mathrm{H}, \mathrm{C}_{5} \mathrm{H}_{4} \mathrm{~N}\right], \delta 5.82\left[\mathrm{~s}, \mathrm{br}, 2 \mathrm{H},-\mathrm{NH}_{2}\right] . \mathrm{X}-$ ray-quality crystals of $\left[\left(4-\mathrm{NH}_{2}-1 \lambda^{4}-\mathrm{C}_{5} \mathrm{H}_{4} \mathrm{~N}\right)_{2}-1 \mu-\mathrm{I}^{+}\right]\left[\mathrm{I}_{7}^{-}\right]\left(2 \cdot \mathrm{I}_{7}^{-}\right)$were obtained by slow evaporation from a $\mathrm{CH}_{2} \mathrm{Cl}_{2}$ solution at $23{ }^{\circ} \mathrm{C}$.

\section{RESULTS AND DISCUSSION}

Reaction of 4-AP with ICl: Formation and Structural Characterization of $\left[4-\mathrm{NH}_{2}-1 \lambda^{4}-\mathrm{C}_{5} \mathrm{H}_{4} \mathrm{~N}-1-\mathrm{ICl}\right](1 \cdot \mathrm{ICl})$, [(4$\left.\left.\mathrm{NH}_{2}-1 \lambda^{4}-\mathrm{C}_{5} \mathrm{H}_{4} \mathrm{~N}\right)_{2}-1-\mu-\mathrm{I}^{+}\right]\left[\mathrm{Cl}^{-}\right]\left(2 \cdot \mathrm{Cl}^{-}\right)$, and $\left[\left(4-\mathrm{NH}_{2}-1 \lambda^{4}-\right.\right.$ $\left.\mathrm{C}_{5} \mathrm{H}_{4} \mathrm{~N}-1-\mathrm{H}^{+}\right]_{2}\left[\mathrm{Cl}^{-}\right]\left[\mathrm{I}_{3}^{-}\right]\left(3_{2} \cdot \mathrm{Cl}^{-} \cdot \mathrm{I}_{3}^{-}\right)$. The reaction of 4-AP with 1 equiv of $\mathrm{ICl}$ was carried out in $\mathrm{CH}_{2} \mathrm{Cl}_{2}$ to afford a red solution and pale red precipitate. The ${ }^{1} \mathrm{H}$ NMR spectrum of the initial powder in $\mathrm{CD}_{3} \mathrm{CN}$ at $30{ }^{\circ} \mathrm{C}$ displays two sets of multiplets arising from the pyridine hydrogens in the range of $6.58-8.06 \mathrm{ppm}$ as well as two singlets at $\delta 5.32$ and 5.72 for the amine groups in an approximate ratio of 4:4:2:2 (Figure S3). At $-20{ }^{\circ} \mathrm{C}$, the signals in the range of $6.58-8.06 \mathrm{ppm}$ show further splitting into four multiplets, while the singlets arising from $\mathrm{NH}_{2}$ groups remain unchanged, giving six signals in equal intensity altogether (Figure S4). Consequently, the ${ }^{1} \mathrm{H}$ NMR data suggest the presence of two independent 4-AP units in the initial reaction powder. Workup of the solution portion (see Experimental Methods) resulted in a brown solid which, on the basis of the ${ }^{1} \mathrm{H}$ NMR spectrum, contained primarily only one of the products observed in the powder portion.

Crystallization efforts of the initial pale red powder in various organic solvents (see Experimental Methods) afforded three different sets of crystals: (1) a structure consisting of a mixture of direct charge-transfer adduct between 4-AP and ICl, [4- $\left.\mathrm{NH}_{2}-1 \lambda^{4}-\mathrm{C}_{5} \mathrm{H}_{4} \mathrm{~N}-1-\mathrm{ICl}\right](\mathbf{1} \cdot \mathrm{ICl})$, and an ionic compound in which the $\mathrm{I}^{+}$cation is trapped between two 4-AP units through $\mathrm{N} \cdots \mathrm{I}^{+} \cdots \mathrm{N}$ contacts, $\left[\left(4-\mathrm{NH}_{2}-1 \lambda^{4}-\mathrm{C}_{5} \mathrm{H}_{4} \mathrm{~N}\right)_{2}-1 \mu-\mathrm{I}^{+}\right]\left[\mathrm{Cl}^{-}\right] \quad(2 \cdot$ $\left.\mathrm{Cl}^{-}\right)$, both in the same crystal lattice (Figure 1a,b), (2) a 


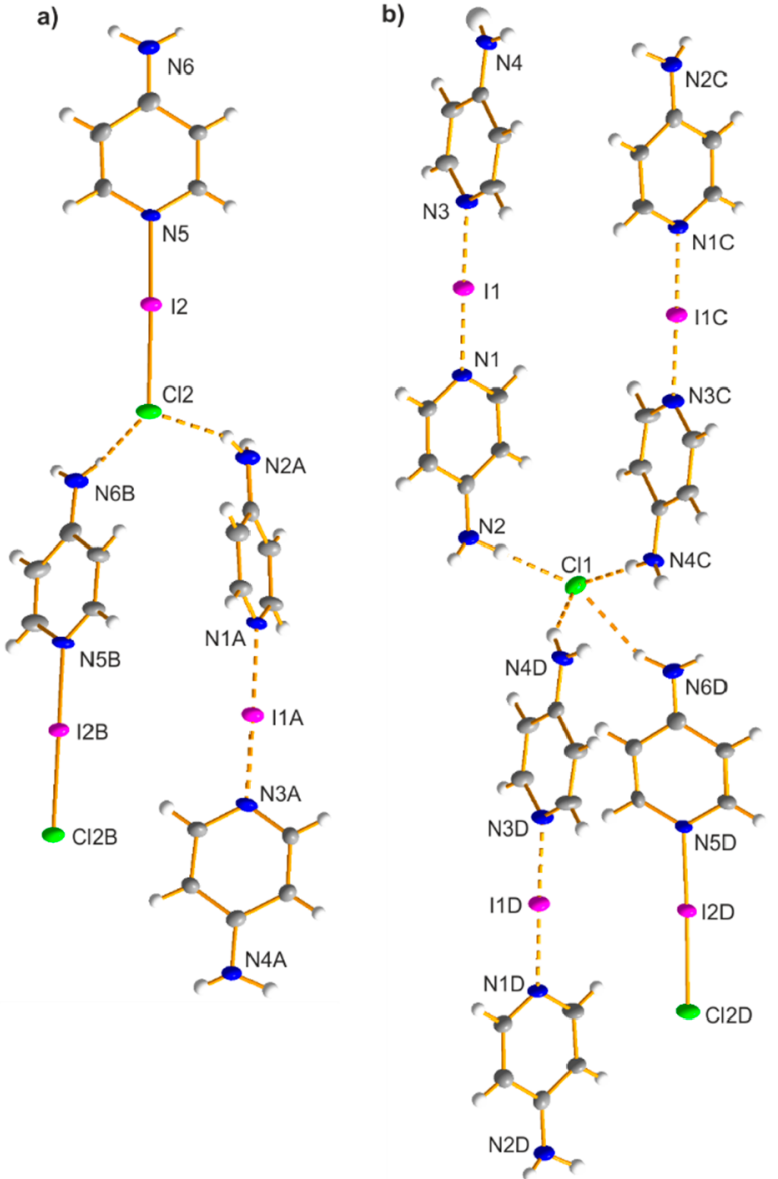

Figure 1. Crystal structure of the cocrystalline $1 \cdot \mathrm{ICl}$ and $2 \cdot \mathrm{Cl}^{-}$ showing $\mathrm{NH} \cdots \mathrm{Cl}$ contacts of (a) the charge-transfer unit and (b) the $\mathrm{Cl}^{-}$anion. Symmetry operations: (A) $1-x, 0.5+y, 2.5-z$; (B) $1+x, 0.5-y, 0.5+z$; (C) $-x,-y, 2-z$; (D) $1+x, y, 1+y$.

structure containing solely the $\mathrm{I}^{+} / \mathrm{Cl}^{-}$ion pair in $2 \cdot \mathrm{Cl}^{-}$(Figure 2 ), and (3) a protonated 4-AP cation with $\mathrm{Cl}^{-}$and $\mathrm{I}_{3}{ }^{-}$ counterions in $\left[\left(4-\mathrm{NH}_{2}-1 \lambda^{4}-\mathrm{C}_{5} \mathrm{H}_{4} \mathrm{~N}-1-\mathrm{H}\right)^{+}\right]_{2}\left[\mathrm{Cl}^{-}\right]\left[\mathrm{I}_{3}^{-}\right]\left(3_{2}\right.$. $\mathrm{Cl}^{-} \cdot \mathrm{I}_{3}{ }^{-}$, Figure 3$)$. While the formation of both $\mathbf{1} \cdot \mathrm{ICl}$ and $2 \cdot$ $\mathrm{Cl}^{-}$is consistent with the observed ${ }^{1} \mathrm{H}$ NMR spectrum of the pale red powder, no protonation of 4-AP is evident in the initial product. Therefore, the appearance of $3_{2} \cdot \mathrm{Cl}^{-} \cdot \mathrm{I}_{3}{ }^{-}$is likely a result of the prolonged crystallization process (Scheme 1). Furthermore, elemental analysis suggests a 2:1 molar ratio between the adduct $\mathbf{1} \cdot \mathrm{ICl}$ and the ionic form $2 \cdot \mathrm{Cl}^{-}$, which is in excellent correspondence with the NMR spectroscopic data; the ${ }^{1} \mathrm{H}$ NMR spectrum of the pale red powder displays a $1: 1$ intensity ratio for the two independent $-\mathrm{NH}_{2}$ singlets arising from the 2:1 molar ratio of $1 \cdot \mathrm{ICl}$ and $2 \cdot \mathrm{Cl}^{-}$due to the one 4$\mathrm{AP}$ unit in the former compound and two 4-AP molecules in the latter compound. Taken together, these data indicate that the equimolar reaction between 4-AP and $\mathrm{ICl}$ in $\mathrm{CH}_{2} \mathrm{Cl}_{2}$ in fact takes place in a 3:2 molar ratio initially. However, as evidenced by the single crystals containing only the ionic form $2 \cdot \mathrm{Cl}^{-}$, the reaction likely does eventually proceed to create the $\mathrm{I}^{+} / \mathrm{Cl}^{-}$ion pair and the compound $2 \cdot \mathrm{Cl}^{-}$as the final product.

The unusual combination of the charge-transfer compound $\mathbf{1} \cdot \mathrm{ICl}$ and the $\mathrm{N} \cdots \mathrm{I}^{+} \cdot \ldots \mathrm{N}$-bridged $2 \cdot \mathrm{Cl}^{-}$crystallizes in the centrosymmetric space group $P 2_{1} / c$ in an equimolar ratio of the two constituents (Figure 1). The two components are organized rather randomly in discrete strands of $\mathbf{1} \cdot \mathrm{ICl}$ and 2 . (a)

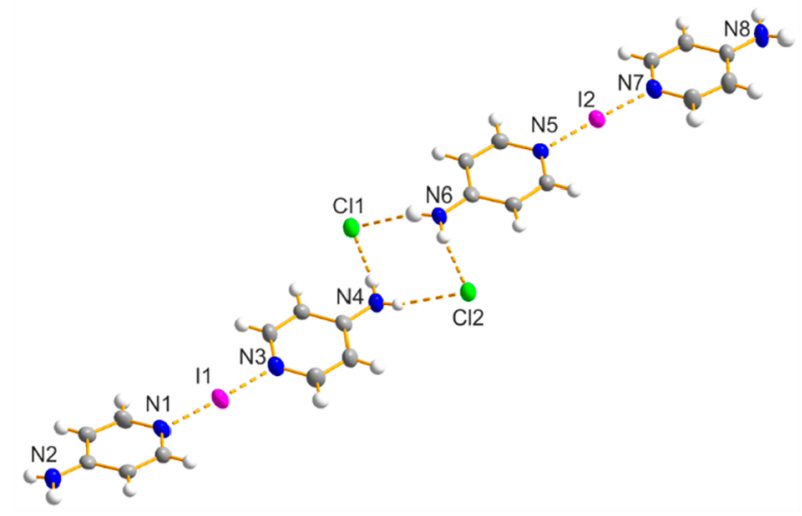

(b)

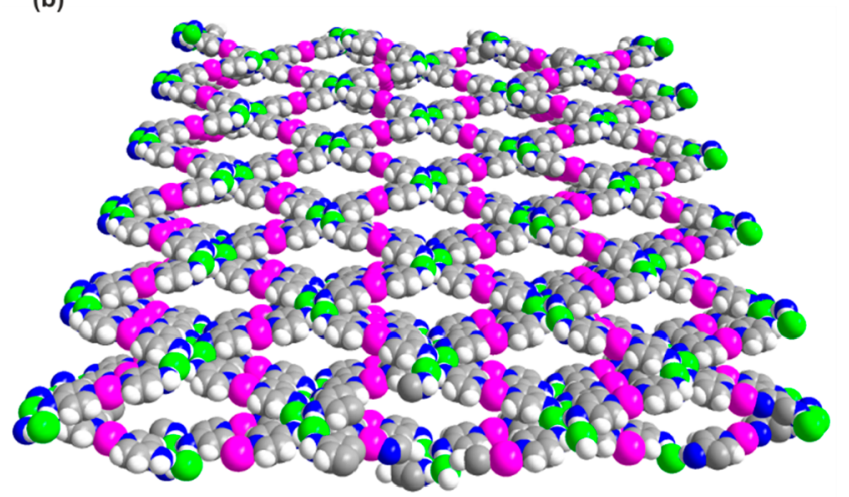

Figure 2. (a) Part of a single strand in $2 \cdot \mathrm{Cl}^{-}$and (b) a space-filling depiction showing the perpendicular formation of strands through $\mathrm{NH} \cdots \mathrm{Cl}$ interactions (van der Waals radii used (in $\AA$ ): I, 1.98; N, 1.55; C, 1.70; H, 1.20; Cl, 1.75).

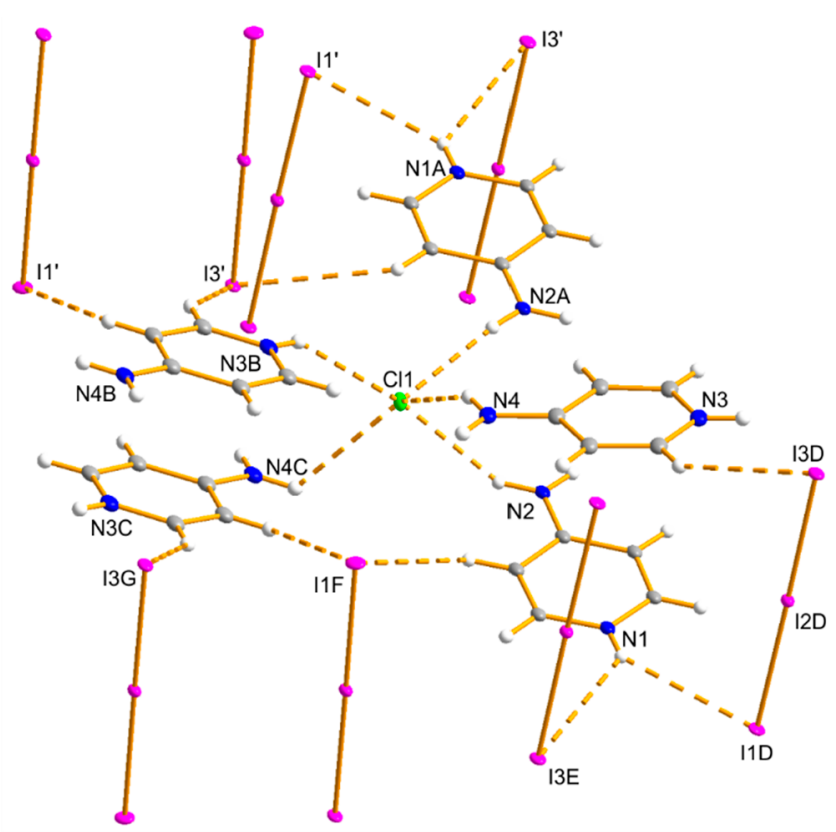

Figure 3. Crystal structure of $3_{2} \cdot \mathrm{Cl}^{-} \cdot \mathrm{I}_{3}{ }^{-}$showing $\mathrm{NH} \cdots \mathrm{Cl}$ and $\mathrm{NH} \cdots \mathrm{I}$ contacts. Symmetry operations: (A) $-1-x,-y,-z$; (B) $-1-x, 0.5$ $+y,-0.5-z$; (C) $x, 0.5-y, 0.5+z$; (D) $-x,-y,-z$; (E) $x, y,-1+$ $z,(\mathrm{~F}) x, 0.5-y,-0.5+z ;(\mathrm{G})-x, 0.5+y, 0.5-z$. 
Table 1. Pertinent Bond Parameters and Close Contacts (in $\AA$ and deg) for the Cocrystalline $\left[4-\mathrm{NH}_{2}-1 \lambda^{4}-\mathrm{C}_{5} \mathrm{H}_{4} \mathrm{~N}-1-\mathrm{ICl}\right](1$. $\mathrm{ICl}),\left[\left(4-\mathrm{NH}_{2}-1 \lambda^{4}-\mathrm{C}_{5} \mathrm{H}_{4} \mathrm{~N}\right)_{2}-1 \mu-\mathrm{I}^{+}\right]\left[\mathrm{Cl}^{-}\right]\left(2 \cdot \mathrm{Cl}^{-}\right),\left[\left(4-\mathrm{NH}_{2}-1 \lambda^{4}-\mathrm{C}_{5} \mathrm{H}_{4} \mathrm{~N}\right)_{2}-1 \mu-\mathrm{I}^{+}\right]\left[\mathrm{Cl}^{-}\right]\left(2 \cdot \mathrm{Cl}^{-}\right)$, and $\left[4-\mathrm{NH}_{2}-1 \lambda^{4}-\mathrm{C}_{5} \mathrm{H}_{4} \mathrm{~N}-1-\right.$ $\left.\mathrm{H}^{+}\right]_{2}\left[\mathrm{Cl}^{-}\right]\left[\mathrm{I}_{3}^{-}\right]\left(3_{2} \cdot \mathrm{Cl}^{-} \cdot \mathrm{I}_{3}^{-}\right)$from ICl Reaction ${ }^{a}$

\begin{tabular}{|c|c|c|c|c|c|}
\hline \multicolumn{2}{|c|}{$1 \cdot \mathrm{ICl} / 2 \cdot \mathrm{Cl}^{-b}$} & \multicolumn{2}{|c|}{$2 \cdot \mathrm{Cl}^{-}$} & \multicolumn{2}{|c|}{$\mathbf{3}_{2} \cdot \mathrm{Cl}^{-} \cdot \mathrm{I}_{3}{ }^{-c}$} \\
\hline $\mathrm{N} 1 \cdots \mathrm{I} 1$ & $2.269(5)[0.64,0.48]$ & $\mathrm{N} 1 \cdots \mathrm{I} 1$ & $2.250(3)[0.64,0.51]$ & N1 1 I1D & $3.690(5)$ \\
\hline $\mathrm{N} 3 \cdots \mathrm{I} 1$ & $2.240(5)[0.64,0.52]$ & $\mathrm{N} 3 \cdots \mathrm{I} 1$ & $2.246(3)[0.64,0.51]$ & N1 $1 \cdots \mathrm{I} 3 \mathrm{E}$ & $3.782(5)$ \\
\hline N5-I2 & $2.186(5)[0.62,0.62]$ & N5 $\cdots \mathrm{I} 2$ & $2.254(2)[0.64,0.50]$ & $\mathrm{N} 2 \cdots \mathrm{Cl} 1$ & $3.275(5)$ \\
\hline $\mathrm{I} 2-\mathrm{Cl} 2$ & $2.634(1)[0.71,0.36]$ & $\mathrm{N} 7 \cdots \mathrm{I} 2$ & $2.240(3)[0.64,0.52]$ & $\mathrm{N} 2 \mathrm{~A} \cdots \mathrm{Cl} 1$ & $3.272(5)$ \\
\hline $\mathrm{N} 2 \cdots \mathrm{Cl} 1$ & $3.284(5)$ & $\mathrm{N} 4 \cdots \mathrm{Cl} 1$ & $3.266(3)$ & $\mathrm{N} 3 \mathrm{~B} \cdots \mathrm{Cl} 1$ & $3.176(6)$ \\
\hline $\mathrm{N} 4 \mathrm{C} \cdots \mathrm{Cl} 1$ & $3.340(6)$ & $\mathrm{N} 4 \cdots \mathrm{Cl} 2$ & $3.279(3)$ & $\mathrm{N} 4 \cdots \mathrm{Cl} 1$ & $3.314(6)$ \\
\hline N6D $\cdots \mathrm{Cl} 1$ & $3.276(5)$ & N6 $\cdots \mathrm{Cl} 1$ & $3.230(3)$ & $\mathrm{N} 4 \mathrm{C} \cdots \mathrm{Cl1}$ & $3.393(5)$ \\
\hline $\mathrm{N} 2 \mathrm{~A} \cdots \mathrm{Cl} 2$ & $3.349(6)$ & $\mathrm{N} 6 \cdots \mathrm{Cl} 2$ & $3.243(3)$ & $\mathrm{I} 1-\mathrm{I} 2$ & $2.9557(3)$ \\
\hline $\mathrm{N} 6 \mathrm{~B} \cdots \mathrm{Cl} 2$ & $3.328(6)$ & & & $\mathrm{I} 2-\mathrm{I} 3$ & $2.9053(5)$ \\
\hline $\mathrm{N} 5-\mathrm{I} 2-\mathrm{Cl} 2$ & $178.4(1)$ & $\mathrm{N} 1 \cdots \mathrm{I} 1 \cdots \mathrm{N} 3$ & $177.2(1)$ & $\mathrm{I} 1-\mathrm{I} 2-\mathrm{I} 3$ & $179.27(2)$ \\
\hline $\mathrm{N} 1 \cdots \mathrm{I} 1 \cdots \mathrm{N} 3$ & $178.3(2)$ & N5 $\cdots 12 \cdots \mathrm{N} 7$ & $177.8(1)$ & $\mathrm{N} 1 \cdots \mathrm{H} \cdots \mathrm{I} 1 \mathrm{D}$ & 134.6 \\
\hline $\mathrm{N} 2 \mathrm{~A} \cdots \mathrm{H} 2^{\prime} \cdots \mathrm{Cl} 2$ & $158(7)$ & $\mathrm{N} 4 \cdots \mathrm{H} 4 \cdots \mathrm{Cl} 1$ & $166(3)$ & $\mathrm{N} 1 \cdots \mathrm{H} \cdots \mathrm{I} 3 \mathrm{E}$ & 130.7 \\
\hline $\mathrm{N} 2 \cdots \mathrm{H} 2 \cdots \mathrm{Cl} 1$ & $177(8)$ & $\mathrm{N} 4 \cdots \mathrm{H} 4^{\prime} \cdots \mathrm{Cl} 2$ & $171(3)$ & $\mathrm{N} 2 \cdots \mathrm{H} \cdots \mathrm{Cl} 1$ & 150.5 \\
\hline $\mathrm{N} 4 \mathrm{C} \cdots \mathrm{H} 4 \cdots \mathrm{Cl} 1$ & $176(8)$ & $\mathrm{N} 6 \cdots \mathrm{H} 6 \cdots \mathrm{Cl} 1$ & $163(3)$ & $\mathrm{N} 2 \mathrm{~A} \cdots \mathrm{H}^{\prime} \cdots \mathrm{Cl} 1$ & 161.9 \\
\hline $\mathrm{N} 4 \mathrm{D} \cdots \mathrm{H} 4^{\prime} \cdots \mathrm{Cl} 1$ & $155(11)$ & $\mathrm{N} 4 \cdots \mathrm{H}^{\prime}{ }^{\prime} \cdots \mathrm{Cl} 2$ & $170(3)$ & $\mathrm{N} 3 \mathrm{~B} \cdots \mathrm{H} \cdots \mathrm{Cl} 1$ & 125.7 \\
\hline $\mathrm{N} 6 \mathrm{~B} \cdots \mathrm{H} 6 \cdots \mathrm{Cl} 2$ & $163(6)$ & & & $\mathrm{N} 4 \cdots \mathrm{H} \cdots \mathrm{Cl} 1$ & 152.8 \\
\hline $\mathrm{N} 6 \mathrm{D} \cdots \mathrm{H} 6^{\prime} \cdots \mathrm{Cl} 1$ & $156(7)$ & & & $\mathrm{N} 4 \mathrm{C} \cdots \mathrm{H}^{\prime} \cdots \mathrm{Cl} 1$ & 123.7 \\
\hline
\end{tabular}

${ }^{a} R_{\mathrm{XB}}$ values (in italics) to evaluate the strength of halogen bonds and calculated bond orders are shown in brackets. $R_{\mathrm{XB}}=d_{\mathrm{XB}} /\left(X_{\mathrm{vdW}}+B_{\mathrm{vdW}}\right)$, where $R_{\mathrm{XB}}=$ strength of $\mathrm{XB}, d_{\mathrm{XB}}=\mathrm{XB}$ distance, and $X_{\mathrm{vdW}}$ and $B_{\mathrm{vdW}}=$ van der Waals radii of $\mathrm{X}$ and $\mathrm{B}$, respectively. ${ }^{67-69}$ Bond orders were calculated by the Pauling equation $N=10^{D-R} / 0.711^{70}$ where $R=$ the observed bond length $(\AA)$ and $D=$ theoretical single-bond length estimated by the sums of appropriate covalent radii $(\AA):{ }^{71} \mathrm{~N}-\mathrm{I}, 2.04$; I-Cl, $2.32 .{ }^{b}$ Symmetry operations: (A) $1-x, 0.5+y, 2.5-z,(\mathrm{~B}) 1+x, 0.5-y, 0.5+z$; (C) $-x$, $-y, 2-z$; (D) $1+x, y, 1+y .{ }^{\circ}$ Symmetry operations: (A) $-1-x,-y,-z$; (B) $-1-x, 0.5+y,-0.5-z$; (C) $x, 0.5-y, 0.5+z,(\mathrm{D})-x,-y,-z$; (E) $x, y,-1+z$.

$\mathrm{Cl}^{-}$, respectively, with two orientations for both compounds. The two pyridine rings around the bridging $\mathrm{N} \cdots \mathrm{I}^{+} \cdots \mathrm{N}$ unit in $2 \cdot \mathrm{Cl}^{-}$are hinged close to $90^{\circ}$ with respect to each other (cf. Figure S1 in the Supporting Information). Overall, the crystal packing is primarily guided by six discrete $\mathrm{NH}_{2} \cdots \mathrm{Cl}$ hydrogen bonds averaging at ca. $2.43 \AA(d(\mathrm{Cl} \cdots \mathrm{N})=3.284(5)-3.349(6)$ A, Table 1). The $\mathrm{N} \cdots \mathrm{I}^{+} \cdots \mathrm{N}$ distances of $2.269(5)$ and $2.240(5)$ $\AA$ in the ionic $\mathbf{2} \cdot \mathrm{Cl}^{-}$are equal within the standard deviation and, expectedly, they are somewhat longer than the corresponding N5-I2 bond length of 2.186(5) $\AA$ in the charge-transfer component $\mathbf{1} \cdot \mathrm{ICl}$ (Table 1). The adjacent I2$\mathrm{Cl} 2$ contact in $\mathbf{1} \cdot \mathrm{ICl}$ displays a distance of 2.634(1) Å. Both the $\mathrm{N} 5-\mathrm{I} 2-\mathrm{Cl} 2$ unit in $\mathbf{1} \cdot \mathrm{ICl}$ and the $\mathrm{N} 1 \cdots \mathrm{I} 1 \cdots \mathrm{N} 3$ portion of 2 . $\mathrm{Cl}^{-}$are nearly linear at $178.4(1)$ and $178.3(2)^{\circ}$, respectively.

The ionic $\mathrm{N} \cdots \mathrm{I}^{+} \cdots \mathrm{N}$ bridging compound $2 \cdot \mathrm{Cl}^{-}$was also obtained as an independent species in tetragonal space group $I 4_{1} / a$ after an extended crystallization period (Figure 2 ). This centrosymmetric structure displays three discrete $\left[\left(4-\mathrm{NH}_{2}-\right.\right.$ $\left.\left.1 \lambda^{4}-\mathrm{C}_{5} \mathrm{H}_{4} \mathrm{~N}\right)_{2}-1 \mu-\mathrm{I}^{+}\right]\left[\mathrm{Cl}^{-}\right]$ion pairs, one of which is created by symmetry. The $2 \cdot \mathrm{Cl}^{-}$units form a $2 \mathrm{D}$ network of cross-linking strands (Figure $2 \mathrm{~b}$ ) through 10 discrete hydrogen bonds with the amine $\mathrm{NH}_{2} \cdots \mathrm{Cl}$ distances between 2.36(4) and 2.58(3) $\AA$ $(d(\mathrm{Cl} \cdots \mathrm{N})=3.230(3)-3.352(3) \AA$, Table S4). In this instance, the pyridine rings in the $\left[\left(4-\mathrm{NH}_{2}-1 \lambda^{4}-\mathrm{C}_{5} \mathrm{H}_{4} \mathrm{~N}\right)_{2}-1 \mu\right.$ $\left.\mathrm{I}^{+}\right]$cations are nearly coplanar and the almost linear $\mathrm{N} \cdots \mathrm{I}^{+} \cdots \mathrm{N}$ contacts $\left(177.2(1)-180^{\circ}\right)$ show distances of $2.240(3)-$ 2.254(2) A that are essentially equal with the corresponding contacts in the $2 \cdot \mathrm{Cl}^{-}$component of the cocrystalline structure containing both $\mathbf{1} \cdot \mathrm{ICl}$ and $2 \cdot \mathrm{Cl}^{-}$(Table 1 ). A search of the CSD database reveals 16 crystal structures of pyridine ${ }^{39}$ and pyridine derivatives (including 2,4,6- $\mathrm{Me}_{3}-\mathrm{PY},{ }^{6,64} 2,6-\mathrm{Me}_{2}-$ $\mathrm{PY}^{65} 4-\mathrm{Me}_{2} \mathrm{~N}-\mathrm{PY},{ }^{66}$ 4-MeO-PY, ${ }^{43}$ and $\left.4-\mathrm{CF}_{3}-\mathrm{PY}^{43}\right)$ with various counteranions containing the $\mathrm{N} \cdots \mathrm{I}^{+} \cdots \mathrm{N}$ bridging unit analogous to that in $2 \cdot \mathrm{Cl}^{-}$. The pertinent bond parameters in $2 \cdot \mathrm{Cl}^{-}$are essentially equal with those reported earlier and support the description of a three-center-four-electron bonding situation in the bridging $\mathrm{N} \cdots \mathrm{I}^{+} \cdots \mathrm{N}$ unit. ${ }^{39,43,63-66}$

In an effort to evaluate the relative strengths of the $\mathrm{N} \cdots \mathrm{I}$ and I... Cl contacts in $1 \cdot \mathrm{ICl}$ and $2 \cdot \mathrm{Cl}^{-}$, the $R_{\mathrm{XB}}$ values for halogen bond strength ${ }^{67-69}$ and the Pauling bond orders ${ }^{70}$ were calculated (cf. selected values in square bracket in Table 1 and a more comprehensive list in Table S3). The $\mathrm{N} \cdots \mathrm{I}^{+} \cdots \mathrm{N}$ close contacts in $2 \cdot \mathrm{Cl}^{-}$exhibit $R_{\mathrm{XB}}$ values of 0.64 and the Pauling bond order averages 0.50 , while the analogous values in $1 \cdot \mathrm{ICl}$ are $0.62\left(R_{\mathrm{XB}}\right)$ and 0.62 (bo) for the N5-I2 bond and 0.71 $\left(R_{\mathrm{XB}}\right)$ and 0.39 (bo) for the $\mathrm{I} 2-\mathrm{Cl} 2$ contact. All these values are indicative of a bonding situation in which the (4-AP)N$\mathrm{I}(\mathrm{Cl})$ bond in $\mathbf{1} \cdot \mathrm{ICl}$ is approaching a covalent single bond, resulting in significant weakening of the adjacent, highly polar $\mathrm{I}$... $\mathrm{Cl}$ contact as is typical for a halogen bond.

Although the ionic compound $\mathbf{2} \cdot \mathrm{Cl}^{-}$is likely the end product from the reaction between 4-AP and $\mathrm{ICl}$, a prolonged crystallization time does result in protonation and formation of $\left[4-\mathrm{NH}_{2}-1 \lambda^{4}-\mathrm{C}_{5} \mathrm{H}_{4} \mathrm{~N}-1-\mathrm{H}^{+}\right]_{2}\left[\mathrm{Cl}^{-}\right]\left[\mathrm{I}_{3}{ }^{-}\right] \quad\left(3_{2} \cdot \mathrm{Cl}^{-} \cdot \mathrm{I}_{3}{ }^{-}\right.$, Figure 3). The crystal structure of $3_{2} \cdot \mathrm{Cl}^{-} \cdot \mathrm{I}_{3}^{-}$consists of two aminopyridinium cations and $\mathrm{Cl}^{-}$and $\mathrm{I}_{3}{ }^{-}$counteranions. The ionic compound crystallizes in the monoclinic space group $P 2_{1} / c$, and the extended $3 \mathrm{D}$ network is formed primarily through weak $\mathrm{NH} \cdots \mathrm{Cl}$ hydrogen bonds $(d(\mathrm{~N} \cdots \mathrm{Cl})=3.176(6)-$ 3.393(5) ^, Table S4) from both the $-\mathrm{NH}_{2}$ unit and the protonated $\mathrm{N}$ atom of the pyridine ring. All of the $\mathrm{NH} \cdots \mathrm{I}$ close contacts to the $\mathrm{I}_{3}{ }^{-}$anion are relatively weak and likely mainly created by the crystal-packing forces. 


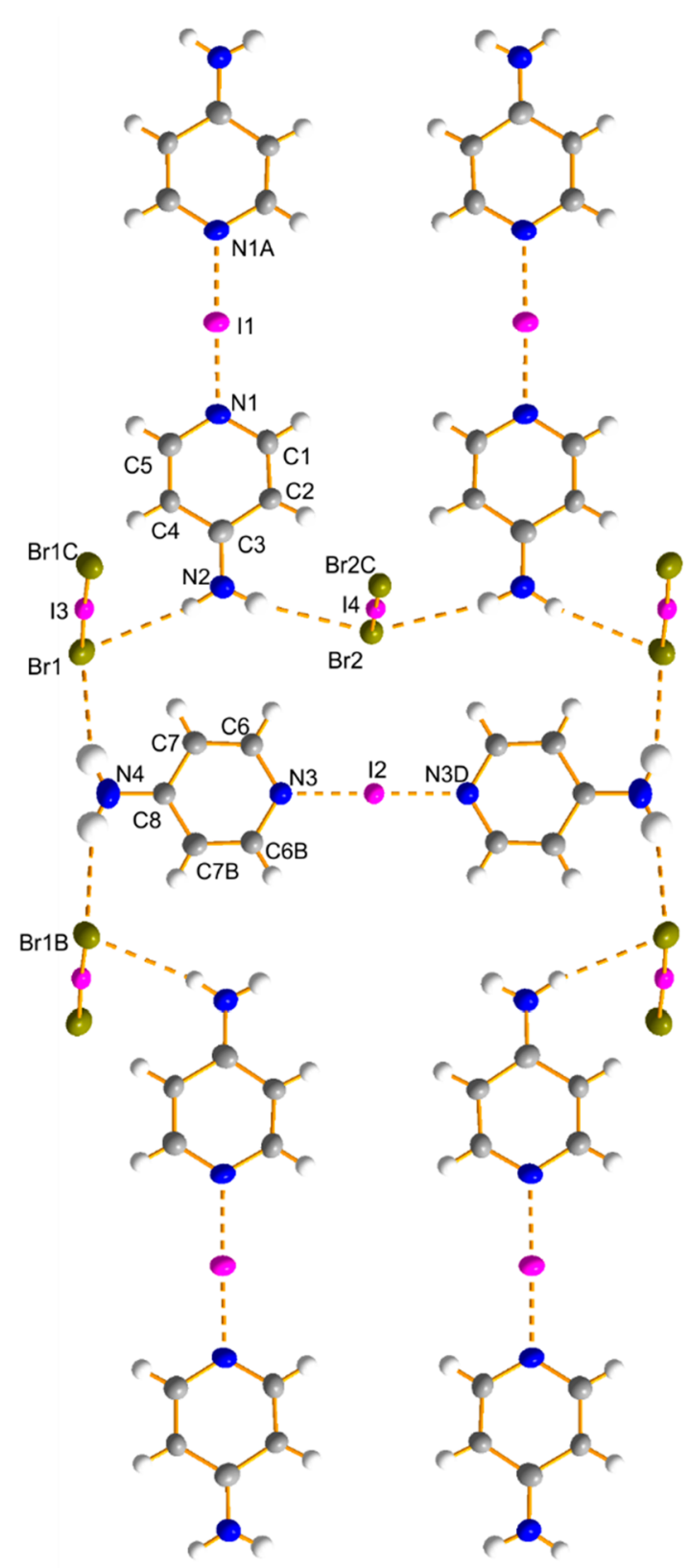

Figure 4. Crystal structure of the monoclinic $2 \cdot \mathrm{IBr}_{2}{ }^{-}$. Symmetry operations: (A) $1-x, y, 1-z$; (B) $2-x, y,-1-z$; (C) $2-x, y$, $-z$; (D) $2-x, 1-y,-1-z$.

Reaction of 4-AP with IBr: Formation and Structural Characterization of Two Polymorphs of $\left[\left(4-\mathrm{NH}_{2}-1 \lambda^{4}-\right.\right.$ $\left.\left.\mathrm{C}_{5} \mathrm{H}_{4} \mathrm{~N}\right)_{2}{ }^{-1} \mu-\mathrm{I}^{+}\right]\left[\mathrm{Br}_{2}{ }^{-}\right]\left(2 \cdot \mathrm{IBr}_{2}{ }^{-}\right)$. The reaction of 4-AP and 1 equiv of $\mathrm{IBr}$ was carried out in $\mathrm{CH}_{2} \mathrm{Cl}_{2}$ to afford an orange precipitate in good yield (79\%). The ${ }^{1} \mathrm{H}$ NMR spectrum of the product in $\mathrm{CD}_{3} \mathrm{CN}$ at $30{ }^{\circ} \mathrm{C}$ displays two multiplets arising from the pyridine hydrogens at 6.57 and $8.05 \mathrm{ppm}$ as well as two singlets at $\delta 5.70$ and 5.83 for the amine groups in a 2:2:1:1 ratio (Figure S5). In contrast to the reaction with $\mathrm{ICl}$, no further splitting of the signals is observed at $-20{ }^{\circ} \mathrm{C}$ (Figure S6), therefore suggesting the formation of only one 4-AP ring with two inequivalent hydrogen atoms in the $-\mathrm{NH}_{2}$ group on the NMR time scale.

Consistently with the formation of $2 \cdot \mathrm{Cl}^{-}$, crystallization of the orange powder by slow evaporation of a $\mathrm{CH}_{2} \mathrm{Cl}_{2}$ solution revealed the existence of the congeneric $\mathrm{N} \cdots \mathrm{I}^{+} \cdots \mathrm{N}$ bridged

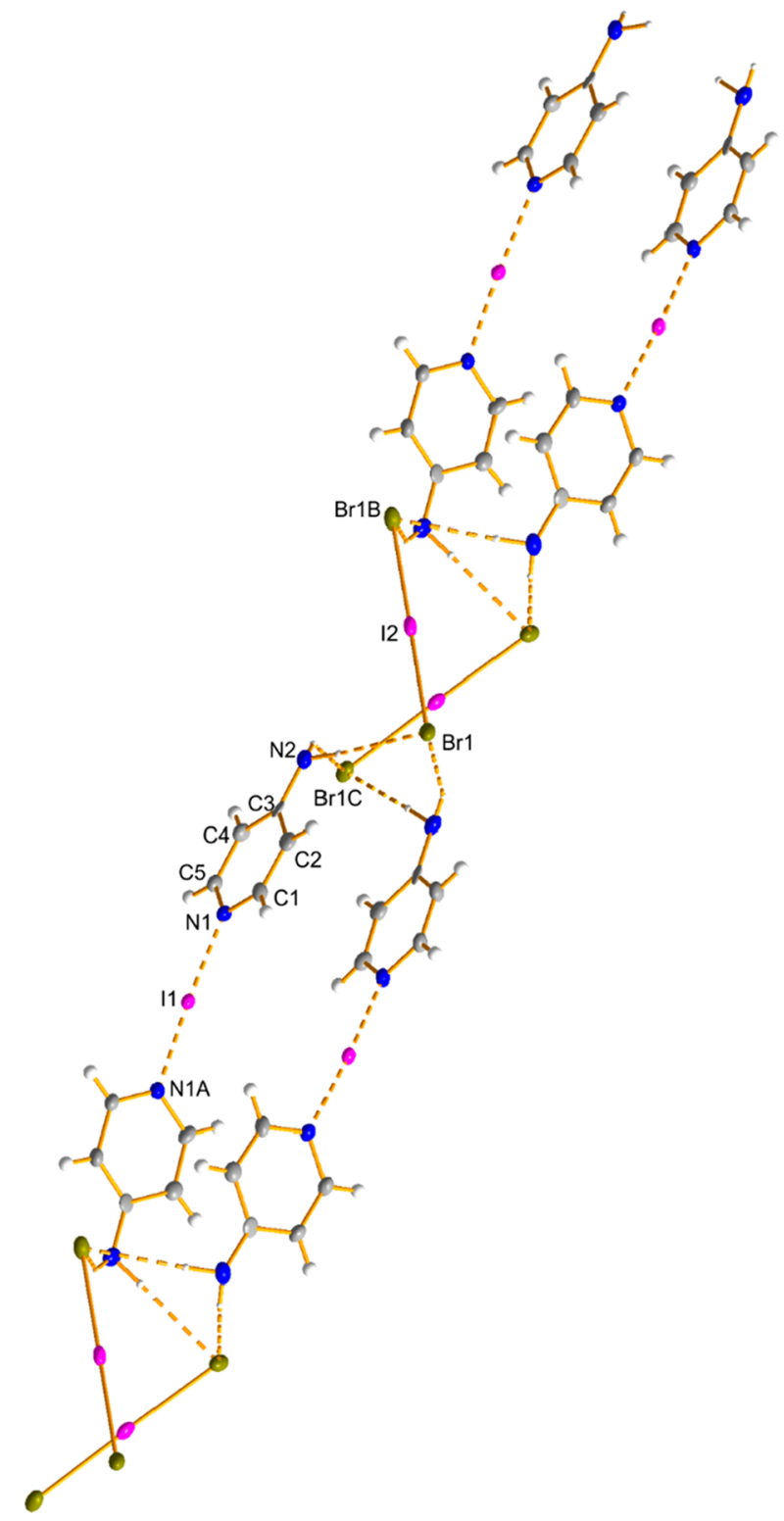

Figure 5. Crystal structure of the orthorhombic $2 \cdot \mathrm{IBr}_{2}{ }^{-}$. Symmetry operations: (A) $0.75-x, 0.75-y, z$; (B) $x, 1.75-y, 0.75-z$; (C) $0.75-x, y, 0.75-z$.

cation with a polyhalide counteranion in $\left[\left(4-\mathrm{NH}_{2}-1 \lambda^{4}\right.\right.$ $\left.\left.\mathrm{C}_{5} \mathrm{H}_{4} \mathrm{~N}\right)_{2}-1 \mu-\mathrm{I}^{+}\right]\left[\mathrm{IBr}_{2}{ }^{-}\right]\left(2 \cdot \mathrm{IBr}_{2}{ }^{-}\right.$, Figures 4 and 5). Two sets of crystals with different morphologies were obtained, yellow plates and orange block-shaped crystals, that were identified as monoclinic and orthorhombic polymorphs of $2 \cdot \mathrm{IBr}_{2}{ }^{-}$, respectively. In contrast to the reaction between 4-AP and $\mathrm{ICl}$, no charge-transfer product analogous to $1 \cdot \mathrm{ICl}$ is observable in the reaction with $\mathrm{IBr}$ in the solid state or in solution (NMR spectroscopy). This is somewhat counterintuitive, given the higher polarity of $\mathrm{ICl}$ in comparison to $\mathrm{IBr}$, but can, possibly, be contributed to the easier formation of the polyiodide anion $\mathrm{IBr}_{2}{ }^{-}$and therefore faster ionization process in the latter reaction (cf. Conclusions). Notably, recently reported experiments performed under similar conditions between the bare, unsubstituted pyridine and $\mathrm{ICl}$ or $\mathrm{IBr}$ resulted in the isolation of only the simple adducts $\left[\mathrm{C}_{5} \mathrm{H}_{4} \mathrm{~N}-1\right.$ IX] $(\mathrm{X}=\mathrm{Cl}, \mathrm{Br})$, without any evidence of ionization. ${ }^{72} \mathrm{~A}$ 
Table 2. Pertinent Bond Parameters and Close Contacts (in $\AA$ and deg) for $\left[\left(4-\mathrm{NH}_{2}-1 \lambda^{4}-\mathrm{C}_{5} \mathrm{H}_{4} \mathrm{~N}\right)_{2^{-}}-1 \mu-\mathrm{I}^{+}\right]\left[\mathrm{IBr}_{2}{ }^{-}\right]\left(2 \cdot \mathrm{IBr}_{2}{ }^{-}\right.$. mono and $2 \cdot \mathrm{IBr}_{2}^{-} \cdot$ ortho), $\left[\left(4-\mathrm{NH}_{2}-1 \lambda^{4}-\mathrm{C}_{5} \mathrm{H}_{4} \mathrm{~N}\right)_{2}-1 \mu-\mathrm{I}^{+}\right]\left[\mathrm{I}_{7}^{-}\right]\left(2 \cdot \mathrm{I}_{7}^{-}\right)$, and $\left[\left(4-\mathrm{NH}_{2}-1 \lambda^{4}-\mathrm{C}_{5} \mathrm{H}_{4} \mathrm{~N}\right)_{2}-1 \mu-\mathrm{H}^{+}\right]\left[\mathrm{I}^{-}\right]\left(6 \cdot \mathrm{I}^{-}\right)$from IBr and $\mathrm{I}_{2}$ Reactions

\begin{tabular}{|c|c|c|c|c|c|c|c|}
\hline \multicolumn{2}{|c|}{$2 \cdot \mathrm{IBr}_{2}^{-} \cdot \mathrm{mono}^{a}$} & \multicolumn{2}{|c|}{$2 \cdot \mathrm{IBr}_{2}{ }^{-} \cdot$ ortho $^{b}$} & \multicolumn{2}{|c|}{$\mathbf{2} \cdot \mathrm{I}_{7}^{-c}$} & \multicolumn{2}{|c|}{$6 \cdot \mathrm{I}^{-d}$} \\
\hline N1 $\cdots$ I1 & $2.242(7)$ & N1 $\cdots \mathrm{I} 1$ & $2.244(5)$ & $\mathrm{N} 1 \cdots \mathrm{I} 1$ & $2.243(5)$ & $\mathrm{N} 1 \cdots \mathrm{H} 1$ & $1.32(5)$ \\
\hline $\mathrm{N} 3 \cdots \mathrm{I} 2$ & $2.228(9)$ & $\mathrm{N} 2 \cdots \mathrm{Br} 1$ & $3.589(6)$ & $\mathrm{N} 2 \cdots \mathrm{I} 2$ & $3.974(6)$ & $\mathrm{N} 1 \cdots \mathrm{N} 3$ & $2.662(5)$ \\
\hline $\mathrm{N} 2 \cdots \mathrm{Br} 1$ & $3.693(7)$ & $\mathrm{N} 2 \cdots \mathrm{Br} 1 \mathrm{C}$ & $3.593(6)$ & $\mathrm{N} 2 \cdots \mathrm{I} 3$ & $3.711(6)$ & $\mathrm{N} 2 \cdots \mathrm{I} 1$ & $3.731(4)$ \\
\hline $\mathrm{N} 2 \cdots \mathrm{Br} 2$ & $3.782(7)$ & $\mathrm{Br} 1-\mathrm{I} 2$ & $2.7309(6)$ & $\mathrm{N} 2 \cdots \mathrm{I} 5$ & $3.962(6)$ & $\mathrm{N} 2 \cdots \mathrm{I} 1 \mathrm{~A}$ & $3.641(4)$ \\
\hline $\mathrm{N} 4 \cdots \mathrm{Br} 1$ & $3.746(2)$ & & & $\mathrm{I} 2-\mathrm{I} 3$ & $2.7535(6)$ & $\mathrm{N} 4 \cdots \mathrm{I} 1$ & $3.667(4)$ \\
\hline $\mathrm{Br} 1-\mathrm{I} 3$ & $2.710(1)$ & & & I4-I5 & $2.9273(4)$ & $\mathrm{N} 4 \cdots \mathrm{I} 1 \mathrm{~A}$ & $3.684(4)$ \\
\hline $\mathrm{Br} 2-\mathrm{I} 4$ & $2.753(1)$ & & & $\mathrm{I} 3 \cdots \mathrm{I} 4$ & $3.2804(6)$ & & \\
\hline N1 $\cdots$ I1 $\cdots$ N1A & $179.0(3)$ & $\mathrm{N} 1 \cdots \mathrm{I} 1 \cdots \mathrm{N} 1 \mathrm{~A}$ & $176.4(2)$ & $\mathrm{N} 1 \cdots \mathrm{I} 1 \cdots \mathrm{N} 1 \mathrm{~A}$ & $180.0(2)$ & $\mathrm{N} 1 \cdots \mathrm{H} 1 \cdots \mathrm{N} 3$ & 160.7 \\
\hline $\mathrm{N} 3 \cdots \mathrm{I} 2 \cdots \mathrm{N} 3 \mathrm{~A}$ & 180 & $\mathrm{Br} 1-\mathrm{I} 2-\mathrm{Br} 1 \mathrm{~B}$ & $176.54(3)$ & I4-I5-I4B & $180.00(1)$ & $\mathrm{N} 2 \cdots \mathrm{H} \cdots \mathrm{I} 1$ & $174(5)$ \\
\hline $\mathrm{Br} 1-\mathrm{I} 3-\mathrm{Br} 1 \mathrm{C}$ & $178.5(1)$ & $\mathrm{N} 2 \cdots \mathrm{H} \cdots \mathrm{Br} 1$ & $172(6)$ & $\mathrm{N} 2 \cdots \mathrm{H} \cdots \mathrm{I} 2$ & $155(7)$ & $\mathrm{N} 2 \cdots \mathrm{H}$ & $165(5)$ \\
\hline $\mathrm{Br} 2-\mathrm{I} 4-\mathrm{Br} 2 \mathrm{C}$ & $180.0(1)$ & $\mathrm{N} 2 \cdots \mathrm{H}^{\prime} \cdots \mathrm{Br} 1 \mathrm{C}$ & $140(6)$ & $\mathrm{N} 2 \cdots \mathrm{H} \cdots \mathrm{I} 3$ & $131(8)$ & $\mathrm{N} 4 \cdots \mathrm{H}^{\prime} \cdots \mathrm{I} 1 \mathrm{~A} \cdots \mathrm{I} 1$ & $166(4)$ \\
\hline $\mathrm{N} 2 \cdots \mathrm{H} \cdots \mathrm{Br} 1$ & $170(8)$ & & & $\mathrm{N} 2 \cdots \mathrm{H}^{\prime} \cdots \mathrm{I} 5$ & $152(6)$ & $\mathrm{N} 4 \cdots \mathrm{H}^{\prime} \cdots \mathrm{I} 1 \mathrm{~A}$ & $165(4)$ \\
\hline $\mathrm{N} 2 \cdots \mathrm{H}^{\prime} \cdots \mathrm{Br} 2$ & $169(10)$ & & & I3 $\cdots$ I4-I5 & $90.61(1)$ & & \\
\hline & & & & $\mathrm{I} 2-\mathrm{I} 3 \cdots \mathrm{I} 4$ & $171.58(2)$ & & \\
\hline
\end{tabular}

${ }^{a}$ Symmetry operations: (A) $1-x, y, 1-z$; (B) $2-x, y,-1-z$; (C) $2-x, y,-z$; (D) $2-x, 1-y,-1-z$. ${ }^{b}$ Symmetry operations: (A) $0.75-x$, $0.75-y, z$; (B) $x, 1.75-y, 0.75-z$; (C) $0.75-x, y, 0.75-z$. ${ }^{c}$ Symmetry operations: (A) $2-x, 1-y, 2-z$; (B) $-1-x, 1-y, 1-z$. ${ }^{d}$ Symmetry operations: (A) $0.5-x,-1.5+y, 1.5-z$; (B) $0.5-x, 0.5+y, 1.5-z$.

further literature survey on the reactions of pyridine derivatives with dihalogens reveals a fine balance between charge-transfer adducts similar to $\mathbf{1} \cdot \mathrm{ICl}$ and the ionic species containing the cation 2: while pyridine and pyridine derivatives $2,4,6-\mathrm{Me}_{3}-\mathrm{PY}$, 3-Br-PY, and 4- $\mathrm{Me}_{2} \mathrm{~N}-\mathrm{PY}$ prefer charge-transfer complexes, the 2,6- $\mathrm{Me}_{2}-\mathrm{PY}$ congener forms ionic species with the $\mathrm{N} \cdots \mathrm{I}^{+} \cdots \mathrm{N}$ unit similarly to 4 -AP. ${ }^{72,73}$

The centrosymmetric, monoclinic polymorph of $2 \cdot \mathrm{IBr}_{2}{ }^{-}$ displays two parallel strands of the $\left[\left(4-\mathrm{NH}_{2}-1 \lambda^{4}-\mathrm{C}_{5} \mathrm{H}_{4} \mathrm{~N}\right)_{2}\right.$ $\left.1 \mu-\mathrm{I}^{+}\right]$units which are separated by analogous, perpendicular cations (Figure 4). The spatial arrangement of the components takes place through weak $\mathrm{NH} \cdots \mathrm{Br}$ contacts $(d(\mathrm{~N} \cdots \mathrm{Br})=$ 3.693(7)-3.782(7) A, Table 2) between the cations and $\mathrm{IBr}_{2}{ }^{-}$ anions. Slight slippage of the layered strands prevents significant $\pi-\pi$ interactions between the 4-AP rings. The orthorhombic polymorph of $\mathbf{2} \cdot \mathrm{IBr}_{2}{ }^{-}$(Figure 5) also crystallizes in a centrosymmetric space group (Fddd). The $\mathrm{NH} \cdots \mathrm{Br}$ connections are somewhat stronger than in the monoclinic form with $d(\mathrm{~N} \cdots \mathrm{Br})=3.589(6)$ and 3.593(6) $\AA$. The $\mathrm{N} \cdots \mathrm{I}^{+} \cdots$ $\mathrm{N}$ distances of $2.228(9)-2.244(5) \AA$ as well as the linearity of this unit $\left(176.2(4)-180^{\circ}\right)$ are analogous to those in $2 \cdot \mathrm{Cl}^{-}$. Unsurprisingly, the $\mathrm{I}-\mathrm{Br}$ bond lengths $(2.7309(6)-2.753(1)$ $\AA$ ) in both polymorphs of $2 \cdot \mathrm{IBr}_{2}{ }^{-}$show typical values for the polyhalide anion. ${ }^{65}$

Reaction of 4-AP with $\mathrm{Br}_{2}$ : Formation and Crystal Structures of $\left[4-\mathrm{NH}_{2}-1 \lambda^{4}-\mathrm{C}_{5} \mathrm{H}_{4} \mathrm{~N}-1-\mathrm{H}^{+}\right]\left[\mathrm{Br}^{-}\right]\left(3 \cdot \mathrm{Br}^{-}\right)$, $\left\{3,3^{\prime}, 5^{\prime}-\mathrm{Br}_{3}-1 \lambda^{4}-\left[1,2^{\prime}-\left(\mathrm{C}_{5} \mathrm{H}_{4} \mathrm{~N}\right)_{2}\right]-4,4^{\prime}-\left(\mathrm{NH}_{2}\right)_{2}\right\}^{+}\left[\mathrm{X}^{-}\right] \quad\left(4 \cdot \mathrm{Br}^{-}\right.$, $\left.4 \cdot \mathrm{Br}_{3}{ }^{-}\right)$, and $\left\{3^{\prime}, 5^{\prime}-\mathrm{Br}_{2}-1 \lambda^{4}-\left[1,2^{\prime}-\left(\mathrm{C}_{5} \mathrm{H}_{4} \mathrm{~N}\right)_{2}\right]-4,4^{\prime}-\right.$ $\left.\left(\mathrm{NH}_{2}\right)_{2}\right\}^{+}\left[\mathrm{X}^{-}\right]\left(5 \cdot \mathrm{Br}^{-}, 5 \cdot \mathrm{Br}_{3}^{-}\right)$. The reaction of 4-AP with 1 equiv of $\mathrm{Br}_{2}$ was carried out in $\mathrm{CH}_{2} \mathrm{Cl}_{2}$ to afford a yellow powder in good yield $\left(74 \%\right.$, calculated as $\left.3 \cdot \mathrm{Br}^{-}\right)$. The ${ }^{1} \mathrm{H}$ NMR spectrum of the product in $\mathrm{CD}_{3} \mathrm{CN}$ (Figure S7) displays typical signal patterns for the pyridine hydrogens at 6.85 and $7.94 \mathrm{ppm}$ and a singlet at $6.60 \mathrm{ppm}$ for the amine group. In addition, a broad multiplet at $\delta 11.29$ with ca. half the intensity in comparison to the other signals was observable in the ${ }^{1} \mathrm{H}$ NMR spectrum, suggesting that protonation of 4-AP has occurred during the reaction.
Crystallization of the yellow product by slow diffusion of THF solution layered with $\mathrm{CH}_{2} \mathrm{Cl}_{2}$ confirmed that, in contrast to the reactions of 4-AP with interhalogens $\mathrm{ICl}$ and $\mathrm{IBr}$, the analogous mixture with $\mathrm{Br}_{2}$ results in an immediate protonation of the 4-AP unit and formation of $\left[4-\mathrm{NH}_{2}-1 \lambda^{4}-\right.$ $\left.\mathrm{C}_{5} \mathrm{H}_{4} \mathrm{~N}-1-\mathrm{H}^{+}\right]\left[\mathrm{Br}^{-}\right]\left(3 \cdot \mathrm{Br}^{-}\right)$as the primary product. ${ }^{74}$ The crystal structure of $3 \cdot \mathrm{Br}^{-}$is comprised of five discrete [4- $\mathrm{NH}_{2}$ $\left.1 \lambda^{4}-\mathrm{C}_{5} \mathrm{H}_{4} \mathrm{~N}-1-\mathrm{H}^{+}\right]\left[\mathrm{Br}^{-}\right]$ion pairs and two $\mathrm{CH}_{2} \mathrm{Cl}_{2}$ solvates (Figure S2) with an extensive hydrogen-bonding network. However, three of the cations 3 and both solvent molecules are disordered, and a detailed structural discussion is therefore ambiguous.

While the reason for the apparent propensity toward protonation in the reaction with $\mathrm{Br}_{2}$ is not clear, ${ }^{74}$ further reactivity of the $4-\mathrm{AP} / \mathrm{Br}_{2}$ mixture is evidenced by multiple products obtained when the reaction mixture is left in solution for $12-14 \mathrm{~h}$. The ${ }^{1} \mathrm{H}$ NMR spectra of the solution shows the appearance of numerous signal patterns, especially in the aromatic region. Subsequent crystallization efforts of the initial yellow product revealed additional chemical transformations to produce brominated pyridyl-pyridinium cations with either two or three bromine substituents in the pyridine rings (Scheme 1); single-crystal X-ray structures of $\left\{3,3^{\prime}, 5^{\prime}-\mathrm{Br}_{3}-1 \lambda^{4}\right.$ $\left.\left[1,2^{\prime}-\left(\mathrm{C}_{5} \mathrm{H}_{4} \mathrm{~N}\right)_{2}\right]-4,4^{\prime}-\left(\mathrm{NH}_{2}\right)_{2}\right\}^{+}\left[\mathrm{X}^{-}\right]\left(4 \cdot \mathrm{Br}^{-}, 4 \cdot \mathrm{Br}_{3}{ }^{-}\right)$and $\left\{3^{\prime}, 5^{\prime}-\mathrm{Br}_{2}-1 \lambda^{4}-\left[1,2^{\prime}-\left(\mathrm{C}_{5} \mathrm{H}_{4} \mathrm{~N}\right)_{2}\right]-4,4^{\prime}-\left(\mathrm{NH}_{2}\right)_{2}\right\}^{+}\left[\mathrm{X}^{-}\right]\left(\mathbf{5} \cdot \mathrm{Br}^{-}, \mathbf{5} \cdot\right.$ $\mathrm{Br}_{3}{ }^{-}$) were determined (Figure 6). In all the structures of 4 and 5 (with $\mathrm{Br}^{-}$and $\mathrm{Br}_{3}^{-}$counterions) a covalent $\mathrm{N}^{+}-\mathrm{C}^{\text {ortho }}$ bond has formed between two pyridine rings. The formally neutral pyridyl ring is disubstituted with $\mathrm{Br}$ atoms in meta positions in both ring systems $\mathbf{4}$ and $\mathbf{5}$, whereas the cationic pyridinium unit is monobrominated in the meta position only in the structures of pyridyl-pyridinium 4 . The bond parameters in 4 and 5 (Table 3) are comparable with those of similar, although only monosubstituted (with $-{ }^{\mathrm{t}} \mathrm{Bu},-\mathrm{NH}_{2}$ and $-\mathrm{S}$ groups), pyridyl-pyridinium cations reported previously. ${ }^{75-79}$

The previously reported $\left[4-\mathrm{R}-1 \lambda^{4}-1,2^{\prime}-\left(\mathrm{C}_{5} \mathrm{H}_{4} \mathrm{~N}\right)_{2}\right]^{+}(\mathrm{R}=$ $\left.{ }^{\mathrm{t}} \mathrm{Bu}, \mathrm{Me}_{2} \mathrm{~N}\right)$ cations comparable to 4 and 5 have been prepared by a direct reaction between the appropriate pyridinium 
a)

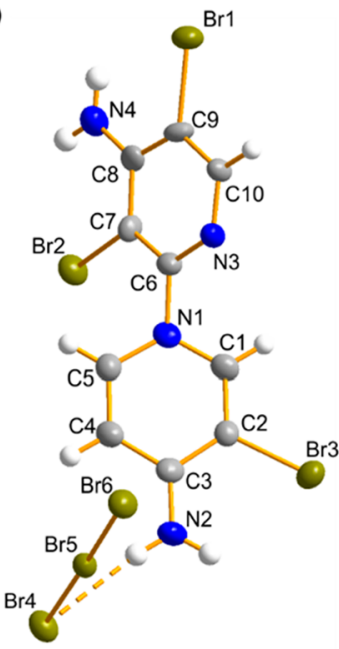

c)
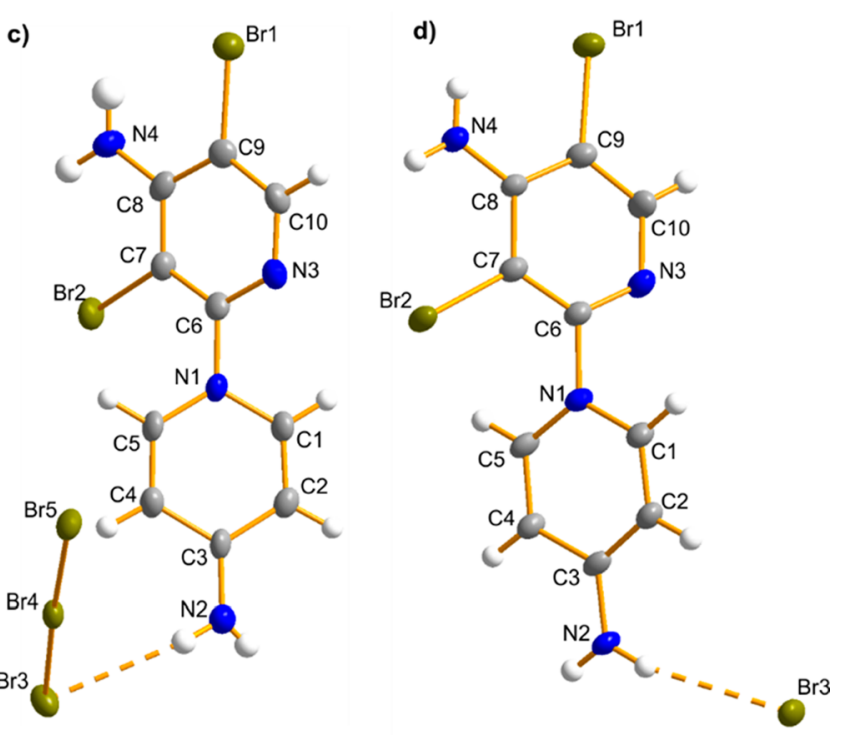

Figure 6. Crystal structures of (a) $4 \cdot \mathrm{Br}_{3}{ }^{-}$, (b) $4 \cdot \mathrm{Br}^{-}$, (c) $5 \cdot \mathrm{Br}_{3}{ }^{-}$, and (d) $5 \cdot \mathrm{Br}^{-}$.

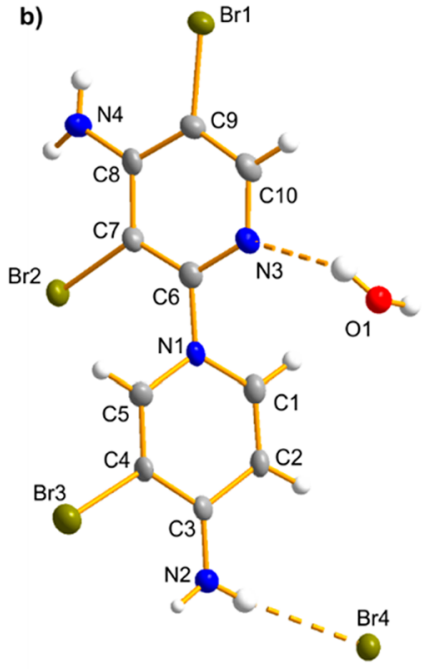

.

(1)

derivative (triflate salt) and neutral pyridine under relatively harsh conditions: a sealed vial under vacuum at $150{ }^{\circ} \mathrm{C} .{ }^{76} \mathrm{It}$ is therefore somewhat surprising that the protonated $3 \cdot \mathrm{Br}^{-}$reacts further in $\mathrm{CH}_{2} \mathrm{Cl}_{2}$ at room temperature to produce pyridylpyridinium cations 4 and $\mathbf{5}$. It is conceivable, however, that a partial cleavage of $\mathrm{HBr}$ acid in the solution of $3 \cdot \mathrm{Br}^{-}$affords a mixture of both components, protonated and neutral 4-AP, required for the direct synthesis of substituted pyridylpyridinium cations. In addition, it has been reported that the equimolar reaction between 2-AP and $\mathrm{Br}_{2}$ in the presence of acetic acid results in bromination of the pyridine ring. ${ }^{80}$ In a similar vein, the acidic condition due to the presence of $\mathrm{HBr}$ could account for the bromination of 4-AP rings and formation of cations 4 and 5 during an extended period in solution.

Reactions of 4-AP with $\mathrm{I}_{2}$ : Formation and Structural Characterization of $\left[\left(4-\mathrm{NH}_{2}-1 \lambda^{4}-\mathrm{C}_{5} \mathrm{H}_{4} \mathrm{~N}\right)_{2}-1 \mu-\mathrm{I}^{+}\right]\left[\mathrm{I}_{7}^{-}\right]$ $\left.\mathrm{I}_{7}^{-}\right)$and $\left[\left(4-\mathrm{NH}_{2}-1 \lambda^{4}-\mathrm{C}_{5} \mathrm{H}_{4} \mathrm{~N}\right)_{2}-1 \mu-\mathrm{H}^{+}\right]\left[\mathrm{I}^{-}\right]\left(6 \cdot \mathrm{I}^{-}\right)$. The reaction of 4-AP with 1 equiv of $\mathrm{I}_{2}$ was carried out in $\mathrm{CH}_{2} \mathrm{Cl}_{2}$, affording a brown precipitate. The ${ }^{1} \mathrm{H}$ NMR spectrum of the product in $\mathrm{CD}_{3} \mathrm{CN}$ (Figure S8) displays four multiplets arising from the pyridine hydrogens in the range of $6.57-8.05 \mathrm{ppm}$ and two singlets at $\delta 5.51$ and 5.83 for the amine groups in approximately equal ratio indicating two inequivalent 4-AP components in solution. Owing to the two discrete 4-AP units and, especially, the well-known ability of iodine to form polyiodides, the reaction between 4-AP and $\mathrm{I}_{2}$ was also performed in a 1:2 molar ratio under similar conditions. The reaction produced a dark red powder, which displays signals at 5.82, 6.59, and $8.04 \mathrm{ppm}$ in a $1: 1: 1$ ratio in the ${ }^{1} \mathrm{H}$ NMR spectrum in $\mathrm{CD}_{3} \mathrm{CN}$ (Figure $\mathrm{S9}$ ), suggesting the formation of only one of the two compounds observed in the reaction in a 1:1 molar ratio as a pure product in good yield (87\%).

Slow evaporation of the $\mathrm{CH}_{2} \mathrm{Cl}_{2}$ solution of the product afforded dark red crystals that were determined as $\left[\left(4-\mathrm{NH}_{2}-\right.\right.$ $\left.\left.1 \lambda^{4}-\mathrm{C}_{5} \mathrm{H}_{4} \mathrm{~N}\right)_{2}-1 \mu-\mathrm{I}^{+}\right]\left[\mathrm{I}_{7}^{-}\right] \quad\left(2 \cdot \mathrm{I}_{7}^{-}\right)$by single-crystal X-ray crystallography (Figure 7). Similarly to the reactions with interhalogens $\mathrm{ICl}$ and $\mathrm{IBr}$, the crystal structure of $2 \cdot \mathrm{I}_{7}{ }^{-}$exhibits an ionic compound with an $\mathrm{I}^{+}$cation trapped between two 4AP units through $\mathrm{N} \cdots \mathrm{I}^{+} \cdots \mathrm{N}$ contacts and an $\mathrm{I}_{7}^{-}$polyiodide counterion. The compound $2 \cdot \mathrm{I}_{7}{ }^{-}$displays symmetry centers both in the cation $\left(\mathrm{N} \cdots \mathrm{I}^{+} \cdots \mathrm{N}\right.$ unit) and in the anion (central $\mathrm{I}_{3}{ }^{-}$). In the latter, the $\mathrm{I} 2-\mathrm{I} 3$ and $\mathrm{I} 3-\mathrm{I} 4$ bond lengths of

Table 3. Pertinent Bond Parameters and Close Contacts (in $\AA$ and deg) for $\left\{3,3^{\prime}, 5^{\prime}-\mathrm{Br}_{3}-1 \lambda^{4}-\left[1,2^{\prime}-\left(\mathrm{C}_{5} \mathrm{H}_{4} \mathrm{~N}\right)_{2}\right]-4,4^{\prime}\right.$ $\left.\left(\mathrm{NH}_{2}\right)_{2}\right\}^{+}\left[\mathrm{X}^{-}\right]\left(4 \cdot \mathrm{Br}^{-}, 4 \cdot \mathrm{Br}_{3}^{-}\right)$and $\left\{3^{\prime}, 5^{\prime}-\mathrm{Br}_{2}-1 \lambda^{4}-\left[1,2^{\prime}-\left(\mathrm{C}_{5} \mathrm{H}_{4} \mathrm{~N}\right)_{2}\right]-4,4^{\prime}-\left(\mathrm{NH}_{2}\right)_{2}\right\}^{+}\left[\mathrm{X}^{-}\right]\left(5 \cdot \mathrm{Br}^{-}, 5 \cdot \mathrm{Br}_{3}^{-}\right)$from $\mathrm{Br}_{2} \mathrm{Reaction}^{-}$

\begin{tabular}{|c|c|c|c|c|c|c|c|}
\hline \multicolumn{2}{|c|}{$4 \cdot \mathrm{Br}^{-}$} & \multicolumn{2}{|c|}{$4 \cdot \mathrm{Br}_{3}^{-}$} & \multicolumn{2}{|c|}{$5 \cdot \mathrm{Br}^{-a}$} & \multicolumn{2}{|c|}{$5 \cdot \mathrm{Br}_{3}^{-b}$} \\
\hline $\mathrm{Br} 1-\mathrm{C} 9$ & $1.894(6)$ & $\mathrm{Br} 1-\mathrm{C} 9$ & $1.910(9)$ & $\mathrm{Br} 1-\mathrm{C} 9$ & $1.898(5)$ & $\mathrm{Br} 1-\mathrm{C} 9$ & $1.893(6)$ \\
\hline $\mathrm{Br} 2-\mathrm{C} 7$ & $1.890(6)$ & $\mathrm{Br} 2-\mathrm{C} 7$ & $1.920(9)$ & $\mathrm{Br} 2-\mathrm{C} 7$ & $1.892(5)$ & $\mathrm{Br} 2-\mathrm{C} 7$ & $1.901(6)$ \\
\hline $\mathrm{Br} 3-\mathrm{C} 4$ & $1.873(6)$ & $\mathrm{Br} 3-\mathrm{C} 2$ & $1.890(9)$ & $\mathrm{Br} 3 \cdots \mathrm{N} 2$ & $3.388(4)$ & $\mathrm{Br} 3 \cdots \mathrm{N} 2$ & $3.542(6)$ \\
\hline $\mathrm{Br} 4 \cdots \mathrm{N} 2$ & $3.339(5)$ & $\mathrm{Br} 4 \cdots \mathrm{N} 2$ & $3.404(9)$ & $\mathrm{Br} 3 \mathrm{~A} \cdots \mathrm{N} 2$ & $3.426(5)$ & $\mathrm{Br} 5 \mathrm{~B} \cdots \mathrm{N} 2$ & $3.461(6)$ \\
\hline $\mathrm{C} 3-\mathrm{C} 4-\mathrm{Br} 3$ & $120.8(4)$ & $\mathrm{C} 1-\mathrm{C} 2-\mathrm{Br} 3$ & $116.8(7)$ & & & & \\
\hline $\mathrm{C} 5-\mathrm{C} 4-\mathrm{Br} 3$ & $117.1(4)$ & $\mathrm{C} 3-\mathrm{C} 2-\mathrm{Br} 3$ & $120.1(7)$ & & & & \\
\hline $\mathrm{C} 6-\mathrm{C} 7-\mathrm{Br} 2$ & $120.8(4)$ & $\mathrm{C} 6-\mathrm{C} 7-\mathrm{Br} 2$ & $122.8(7)$ & $\mathrm{C} 6-\mathrm{C} 7-\mathrm{Br} 2$ & $121.5(4)$ & $\mathrm{C} 6-\mathrm{C} 7-\mathrm{Br} 2$ & $122.4(4)$ \\
\hline $\mathrm{C} 8-\mathrm{C} 7-\mathrm{Br} 2$ & $119.0(4)$ & $\mathrm{C} 8-\mathrm{C} 7-\mathrm{Br} 2$ & $115.5(7)$ & $\mathrm{C} 8-\mathrm{C} 7-\mathrm{Br} 2$ & $118.8(4)$ & $\mathrm{C} 8-\mathrm{C} 7-\mathrm{Br} 2$ & $117.5(4)$ \\
\hline $\mathrm{C} 8-\mathrm{C} 9-\mathrm{Br} 1$ & $120.5(5)$ & $\mathrm{C} 8-\mathrm{C} 9-\mathrm{Br} 1$ & $118.1(7)$ & $\mathrm{C} 8-\mathrm{C} 9-\mathrm{Br} 1$ & $120.5(4)$ & $\mathrm{C} 8-\mathrm{C} 9-\mathrm{Br} 1$ & $118.5(5)$ \\
\hline $\mathrm{C} 10-\mathrm{C} 9-\mathrm{Br} 1$ & $118.6(4)$ & $\mathrm{C} 10-\mathrm{C} 9-\mathrm{Br} 1$ & $118.4(7)$ & $\mathrm{C} 10-\mathrm{C} 9-\mathrm{Br} 1$ & $117.7(4)$ & $\mathrm{C} 10-\mathrm{C} 9-\mathrm{Br} 1$ & $120.6(5)$ \\
\hline \multirow[t]{2}{*}{$\mathrm{N} 2 \cdots \mathrm{H} \cdots \mathrm{Br} 4$} & $167(8)$ & $\mathrm{N} 2 \cdots \mathrm{H} \cdots \mathrm{Br} 4$ & 168.0 & $\mathrm{~N} 2 \cdots \mathrm{H} \cdots \mathrm{Br} 3$ & 155.5 & $\mathrm{~N} 2 \cdots \mathrm{H} \cdots \mathrm{Br} 3$ & $164(8)$ \\
\hline & & & & $\mathrm{N} 2 \cdots \mathrm{H}^{\prime} \cdots \mathrm{Br} 3 \mathrm{~A}$ & 149.4 & $\mathrm{~N} 2 \cdots \mathrm{H}^{\prime} \cdots \mathrm{Br} 5 \mathrm{~B}$ & $139(10)$ \\
\hline
\end{tabular}

${ }^{a}$ Symmetry operations: (A) $1-x,-0.5+y,-0.5-z$ (Br3A not shown in Figure $\left.6 \mathrm{~d}\right) .{ }^{b}$ Symmetry operations: (B) $2-x, 1-y, 2-z(\mathrm{Br} 5 \mathrm{~B}$ not shown in Figure 6c). 


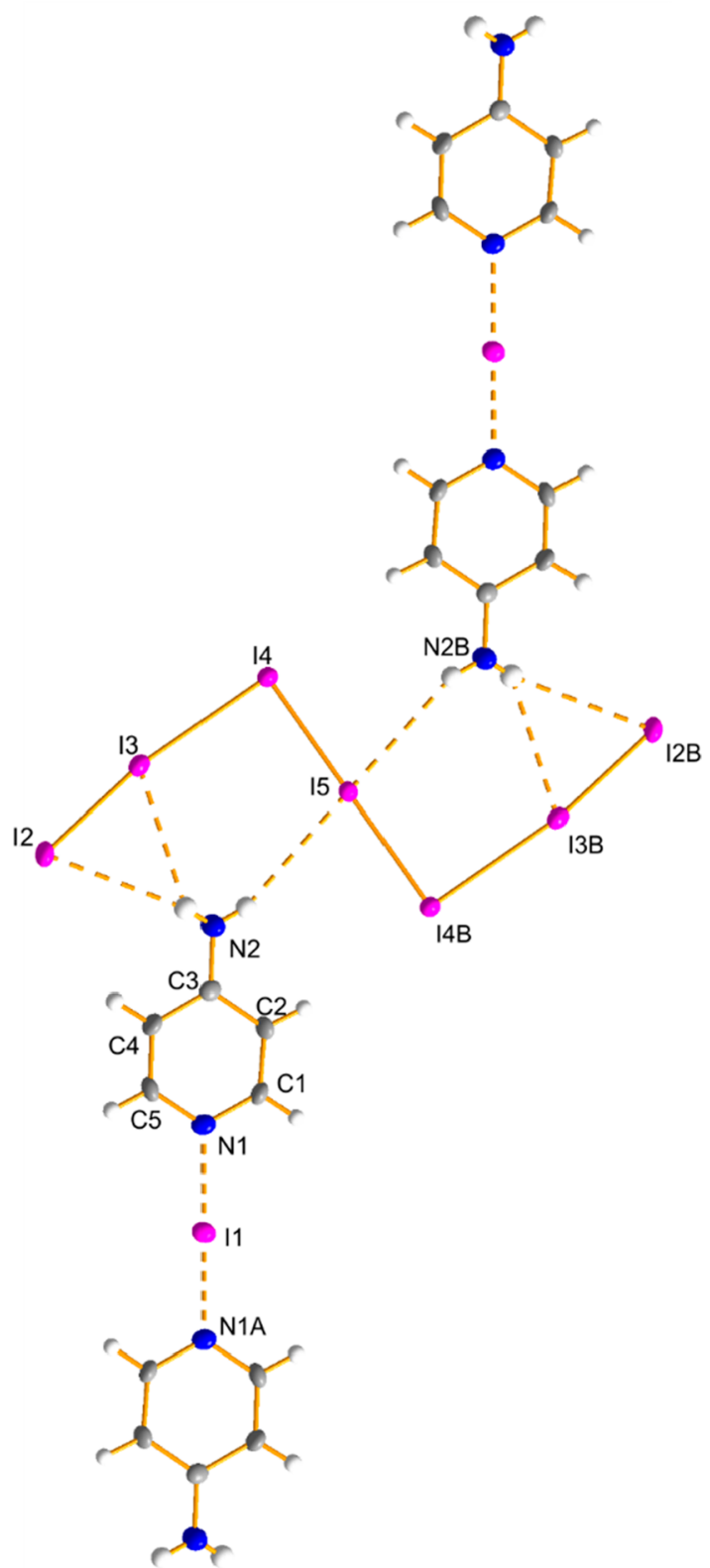

Figure 7. Crystal structure of $2 \cdot \mathrm{I}_{7}^{-}$. Symmetry operations: (A) $2-x$, $1-y, 2-z$; (B) $-1-x, 1-y, 1-z$.

2.7535(6) and 2.9273(4) A, respectively (Table 2), along with

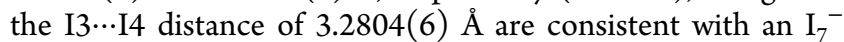
component comprised of two neutral $\mathrm{I}_{2}$ units and one $\mathrm{I}_{3}^{-}$ anion. The ion pairs are connected to infinite strands through weak $\mathrm{NH} \cdots \mathrm{I}$ contacts $(d(\mathrm{~N} \cdots \mathrm{I})=3.711(6)-3.974(6) \AA$, Table S5). The 4-AP rings around the $\mathrm{I}^{+}$cation are essentially coplanar, and the $\mathrm{N} \cdots \mathrm{I}^{+} \cdots \mathrm{N}$ distance of $2.244(5) \AA$ is equal to those observed for $2 \cdot \mathrm{Cl}^{-}$and $2 \cdot \mathrm{IBr}_{2}{ }^{-}$. The formation of $2 \cdot \mathrm{I}_{7}^{-}$is consistent with the analogous reaction between unsubstituted pyridine and 2 equiv of $\mathrm{I}_{2}$. ${ }^{48}$

Similarly to the $\mathrm{Br}_{2}$ reaction, the proclivity for protonation of $2 \cdot \mathrm{I}_{7}{ }^{-}$is evident from the single-crystal structures of $\left[\left(4-\mathrm{NH}_{2}-\right.\right.$ $\left.\left.1 \lambda^{4}-\mathrm{C}_{5} \mathrm{H}_{4} \mathrm{~N}\right)_{2}-1 \mu-\mathrm{H}^{+}\right]\left[\mathrm{I}^{-}\right]\left(6 \cdot \mathrm{I}^{-}\right.$, Figure 8$)$ and the previously reported $\left[4-\mathrm{NH}_{2}-1 \lambda^{4}-\mathrm{C}_{5} \mathrm{H}_{4} \mathrm{~N}-1-\mathrm{H}^{+}\right]_{2}\left[\mathrm{I}^{-}\right]\left[\mathrm{I}_{3}{ }^{-}\right]$(CCDC $1403481)^{62}$ obtained after long standing of the product in various solvents (Scheme 1). The centrosymmetric crystal structure of $6 \cdot \mathrm{I}^{-}$is comprised of an $\mathrm{H}^{+}$cation trapped between

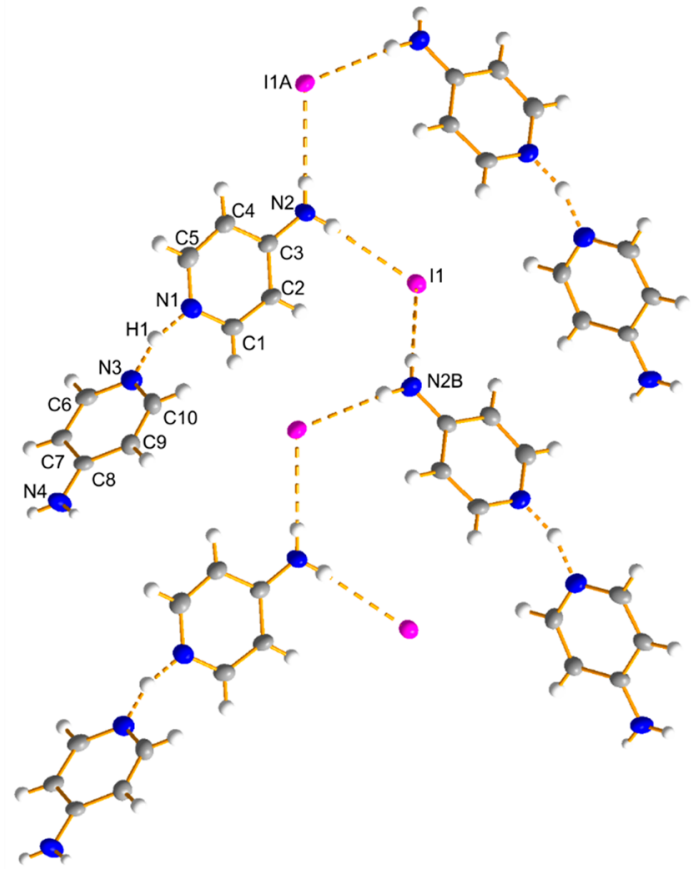

Figure 8. Crystal structure of $6 \cdot \mathrm{I}^{-}$. Symmetry operations: (A) $0.5-x$, $-1.5+y, 1.5-z$; (B) $0.5-x, 0.5+y, 1.5-z$.

two 4-AP rings by $\mathrm{N} \cdots \mathrm{H}^{+} \cdots \mathrm{N}$ contacts and an $\mathrm{I}^{-}$counteranion (Figure 8). The ion pairs form cross-linking strands through four $\mathrm{NH} \cdots \mathrm{I}$ contacts of ca. $2.88 \AA(d(\mathrm{~N} \cdots \mathrm{I})=3.641(4)-$ 3.731(4) A, Table S5). The CSD database contains 12 structures in which a proton is trapped between two pyridine or substituted pyridine units. Both coplanar and perpendicular arrangements of the pyridine rings exist with $\mathrm{N} \cdots \mathrm{N}$ distance of ca. $2.58-2.68 \AA$ in the nearly linear $\mathrm{N} \cdots \mathrm{H}^{+} \cdots \mathrm{N}$ units (177$\left.180^{\circ}\right)$. While the $\mathrm{N} 1 \cdots \mathrm{N} 3$ distance of $2.662(5) \AA$ in $6 \cdot \mathrm{I}^{-}$falls within same range with the previously reported values, the distinctive tilting between the pyridines is clearly noticeable in the $\mathrm{N} 1 \cdots \mathrm{H} 1 \cdots \mathrm{N} 3$ angle of $160.7^{\circ}$ (Table 2 ) in comparison to the value of $172^{\circ}$, representing the narrowest angle in the corresponding systems. ${ }^{81}$

\section{CONCLUSIONS}

The reactions of 4-aminopyridine (4-AP) with dihalogens ( $\mathrm{ICl}$, $\mathrm{IBr}, \mathrm{Br}_{2}$, and $\left.\mathrm{I}_{2}\right)$ reveal versatile chemical and structural behavior. Intriguingly, the chemical transformation between 4$\mathrm{AP}$ and $\mathrm{ICl}$ in a 1:1 molar ratio results in the formation of both the charge-transfer adduct $\mathbf{1} \cdot \mathrm{ICl}$ and the iodonium cation in $\mathbf{2}$. $\mathrm{Cl}^{-}$. Although the two basic units in these compounds, neutral $\mathrm{C}_{5} \mathrm{H}_{4} \mathrm{~N}-\mathrm{ICl}$ and $\mathrm{C}_{5} \mathrm{H}_{4} \mathrm{~N} \cdots \mathrm{I}^{+} \cdots \mathrm{NH}_{4} \mathrm{C}_{5}$ cation, have been wellcharacterized in various pyridine derivates, this is the first time the coexistence of both components has been observed in solution (NMR) and as a cocrystalline material in the solid state. Moreover, to the best of our knowledge the unsubstituted pyridine (PY) is the only congener for which both the charge-transfer $\mathrm{C}_{5} \mathrm{H}_{4} \mathrm{~N}-\mathrm{I}_{2}^{82}$ and ionic $\mathrm{C}_{5} \mathrm{H}_{4} \mathrm{~N} \cdots \mathrm{I}^{+} \ldots$ $\mathrm{NH}_{4} \mathrm{C}_{5}^{48}$ forms have been structurally characterized by X-ray crystallography in independent investigations.

Somewhat surprisingly, the analogous reaction between 4$\mathrm{AP}$ and $\mathrm{IBr}$ affords solely the iodonium salt $\left[\left(4-\mathrm{NH}_{2}-1 \lambda^{4}\right.\right.$ $\left.\left.\mathrm{C}_{5} \mathrm{H}_{4} \mathrm{~N}\right)_{2}-1 \mu-\mathrm{I}^{+}\right]\left[\mathrm{IBr}_{2}{ }^{-}\right]\left(2 \cdot \mathrm{IBr}_{2}{ }^{-}\right)$with polyhalide as the counteranion despite the lower polarity of $\mathrm{IBr}$ in comparison to ICl. Consistently, 1 equiv of virtually nonpolar $\mathrm{I}_{2}$ also reacts 
with 4-AP to produce the $\mathrm{I}^{+}$cation in $\left[\left(4-\mathrm{NH}_{2}-1 \lambda^{4}-\mathrm{C}_{5} \mathrm{H}_{4} \mathrm{~N}\right)_{2}\right.$ $\left.1 \mu-\mathrm{I}^{+}\right]\left[\mathrm{I}_{7}^{-}\right]\left(2 \cdot \mathrm{I}_{7}^{-}\right)$without any evidence of a charge-transfer compound comparable to $\mathbf{1} \cdot \mathrm{ICl}$. In this instance, additional iodine is also needed for the formation of $\mathrm{I}_{7}^{-}$polyiodide instead of triiodide $\mathrm{I}_{3}{ }^{-}$analogous to $\mathrm{IBr}_{2}{ }^{-}$and, consequently, the reaction between $I_{2}$ and 4-AP takes place in a 2:1 molar ratio. A series of the charge-transfer compounds comparable to $\mathbf{1} \cdot \mathrm{ICl}$ has been previously reported for unsubstituted pyridine, $\mathrm{C}_{5} \mathrm{H}_{4} \mathrm{~N}-\mathrm{IX}(\mathrm{X}=\mathrm{Cl}, \mathrm{Br}, \mathrm{I}){ }^{72,82}$ In these compounds, the N$\mathrm{I}(\mathrm{X})$ bond lengths of 2.284(3) $(\mathrm{X}=\mathrm{Cl}),{ }^{72} 2.304(3)(\mathrm{X}=$ $\mathrm{Br}),{ }^{72}$ and $2.425(8) \AA(\mathrm{X}=\mathrm{I}),{ }^{82}$ and the calculated $(\mathrm{N}) \mathrm{I}-\mathrm{X}$ bond orders ${ }^{70}$ of $0.52\left(d(\mathrm{I}-\mathrm{Cl})=2.523(1) \AA^{72}\right), 0.54(d(\mathrm{I}-$ $\left.\mathrm{Br})=2.654(1) \AA^{72}\right)$, and $0.75\left(d(\mathrm{I}-\mathrm{I})=2.8043(9) \AA^{82}\right)$ display the expected trend: the $\mathrm{N}-\mathrm{I}$ bond is strengthening and the $\mathrm{I}-\mathrm{X}$ bond is weakening when the polarity of the IX component is increasing $\left(\mathrm{ICl}>\mathrm{IBr}>\mathrm{I}_{2}\right)$. In light of these data, stabilization of the charge-transfer compound $1 \cdot \mathrm{ICl}$ and, in contrast, the apparent ready formation of the iodonium cation in $2 \cdot \mathrm{IBr}_{2}{ }^{-}$and $2 \cdot \mathrm{I}_{7}^{-}$is somewhat surprising. It is conceivable, however, that the easier formation of the polyhalides $\mathrm{IBr}_{2}{ }^{-}$and $\mathrm{I}_{7}^{-}$in comparison to the reaction with $\mathrm{ICl}$ provides the driving force for a rapid cleavage of the $\mathrm{I}-\mathrm{Br}$ and $\mathrm{I}-\mathrm{I}$ bonds and subsequent formation of an iodonium cation. On the basis of this study and a literature survey, there is a fine balance between the two components that, presumably, can also be controlled by the selection of substituents.

The chemical transformation between 4-AP and $\mathrm{Br}_{2}$ exhibits unique reactivity in comparison to those involving $\mathrm{ICl}, \mathrm{IBr}$, and $\mathrm{I}_{2}$. The reaction displays immediate protonation of the 4-AP ring, affording $\left[4-\mathrm{NH}_{2}-1 \lambda^{4}-\mathrm{C}_{5} \mathrm{H}_{4} \mathrm{~N}-1-\mathrm{H}^{+}\right]\left[\mathrm{Br}^{-}\right]\left(3 \cdot \mathrm{Br}^{-}\right)$as the initial product. While the presence of a catalytic amount of $\mathrm{HBr}$ in the starting material to initiate the protonation cannot be completely ruled out, ${ }^{74}$ the subsequent intriguing bromination-dimerization process and formation of pyridylpyridinium cations 4 and 5 indicates greater reactivity in the reactions with $\mathrm{Br}_{2}$ in comparison to those of the other dihalogens. Consequently, the present study shows that, while the reactions between 4-AP and $\mathrm{ICl}, \mathrm{IBr}$, and $\mathrm{I}_{2}$ conveniently produce $\mathrm{N} \cdots \mathrm{I}^{+} \cdots \mathrm{N}$-bonded iodonium cations, potentially useful $\mathrm{XB}$ donors in applications, the chemical transformation with $\mathrm{Br}_{2}$ is much more complex and the observed brominationdimerization process merits further investigations.

\section{ASSOCIATED CONTENT}

\section{S Supporting Information}

The Supporting Information is available free of charge on the ACS Publications website at DOI: 10.1021/acs.cgd.9b00119.

Crystallographic data, halogen bond geometries, and pertinent bond parameters for all compounds, crystallographic figures of compounds $1 \cdot \mathrm{ICl}$ and $2 \cdot \mathrm{Cl}^{-}$and $3 \cdot \mathrm{Br}^{-}$, and ${ }^{1} \mathrm{H}$ NMR spectra of the bulk products (PDF)

\section{Accession Codes}

CCDC 1893191-1893202 contain the supplementary crystallographic data for this paper. These data can be obtained free of charge via www.ccdc.cam.ac.uk/data_request/cif, or by emailing data_request@ccdc.cam.ac.uk, or by contacting The Cambridge Crystallographic Data Centre, 12 Union Road, Cambridge CB2 1EZ, UK; fax: +44 1223336033.

\section{AUTHOR INFORMATION}

\section{Corresponding Author}

*J.K.: e-mail, jari.a.konu@jyu.fi; tel, +358-40-805-4406.

\section{ORCID}

Matti Haukka: 0000-0002-6744-7208

Jari Konu: 0000-0002-7408-8995

\section{Notes}

The authors declare no competing financial interest.

\section{ACKNOWLEDGMENTS}

The authors gratefully acknowledge financial support from Jenny and Antti Wihuri Foundation, Magnus Ehrnrooth Foundation and the Academy of Finland (E.K, M.H., Project No. 295581).

\section{REFERENCES}

(1) Guthrie, F. XXVIII.-On the Iodide of Iodammonium. J. Chem. Soc. 1863, 16, 239-244.

(2) Moore, T. S.; Winmill, T. F. CLXXVII.-The State of Amines in Aqueous Solution. J. Chem. Soc., Trans. 1912, 101, 1635-1676.

(3) Řezáć, J.; Riley, K. E.; Hobza, P. Benchmark Calculations of Noncovalent Interactions of Halogenated Molecules. J. Chem. Theory Comput. 2012, 8 (11), 4285-4292.

(4) Bundhun, A.; Ramasami, P.; Murray, J. S.; Politzer, P. Trends in $\sigma$-Hole Strengths and Interactions of $\mathrm{F}_{3} \mathrm{MX}$ Molecules $(\mathrm{M}=\mathrm{C}, \mathrm{Si}, \mathrm{Ge}$ and X = F, Cl, Br, I). J. Mol. Model. 2013, 19 (7), 2739-2746.

(5) Kozuch, S.; Martin, J. M. L. Halogen Bonds: Benchmarks and Theoretical Analysis. J. Chem. Theory Comput. 2013, 9 (4), 19181931.

(6) Politzer, P.; Murray, J. S.; Clark, T. Halogen Bonding and Other $\sigma$-Hole Interactions: A Perspective. Phys. Chem. Chem. Phys. 2013, 15 (27), 11178-11189.

(7) Syzgantseva, O. A.; Tognetti, V.; Joubert, L. On the Physical Nature of Halogen Bonds: A QTAIM Study. J. Phys. Chem. A 2013, 117 (36), 8969-8980.

(8) Mitoraj, M. P.; Michalak, A. Theoretical Description of Halogen Bonding - an Insight Based on the Natural Orbitals for Chemical Valence Combined with the Extended-Transition-State Method (ETS-NOCV). J. Mol. Model. 2013, 19 (11), 4681-4688.

(9) Mu, X.; Wang, Q.; Wang, L.-P.; Fried, S. D.; Piquemal, J.-P.; Dalby, K. N.; Ren, P. Modeling Organochlorine Compounds and the $\sigma$-Hole Effect Using a Polarizable Multipole Force Field. J. Phys. Chem. B 2014, 118 (24), 6456-6465.

(10) Wang, C.; Danovich, D.; Mo, Y.; Shaik, S. On The Nature of the Halogen Bond. J. Chem. Theory Comput. 2014, 10 (9), 37263737.

(11) Arman, H. D.; Biella, S.; Bruce, D. W.; Fourmigué, M.; Hanks, T. W.; Karpfen, A.; Kochi, J. K.; Legon, A. C.; Metrangolo, P.; Pennington, W. T.; et al. Halogen Bonding: Fundamentals and Applications; Metrangolo, P., Resnati, G., Eds.; Springer-Verlag: Berlin, Heidelberg, 2008; Vol. 126.

(12) Cavallo, G.; Metrangolo, P.; Pilati, T.; Resnati, G.; Sansotera, M.; Terraneo, G. Halogen Bonding: A General Route in Anion Recognition and Coordination. Chem. Soc. Rev. 2010, 39 (10), 37723783.

(13) Bertani, R.; Sgarbossa, P.; Venzo, A.; Lelj, F.; Amati, M.; Resnati, G.; Pilati, T.; Metrangolo, P.; Terraneo, G. Halogen Bonding in Metal-organic-supramolecular Networks. Coord. Chem. Rev. 2010, 254 (5-6), 677-695.

(14) Ding, X.; Tuikka, M.; Haukka, M. Halogen Bonding in Crystal Engineering. In Recent Advances in Crystallography; Benedict, J. B., Ed.; InTech: New York, 2012; pp 143-168.

(15) Priimagi, A.; Cavallo, G.; Metrangolo, P.; Resnati, G. The Halogen Bond in the Design of Functional Supramolecular Materials: Recent Advances. Acc. Chem. Res. 2013, 46 (11), 2686-2695.

(16) Mukherjee, A.; Tothadi, S.; Desiraju, G. R. Halogen Bonds in Crystal Engineering: Like Hydrogen Bonds yet Different. Acc. Chem. Res. 2014, 47 (8), 2514-2524.

(17) Rissanen, K.; Haukka, M. Halonium Ions as Halogen Bond Donors in the Solid State $\left[\mathrm{XL}_{2}\right]$ Y Complexes. In Halogen Bonding II. 
Topics in Current Chemistry; Metrangolo, P., Resnati, G., Eds.; Springer: Cham, Switzerland, 2015; pp 77-90.

(18) Cavallo, G.; Metrangolo, P.; Milani, R.; Pilati, T.; Priimagi, A.; Resnati, G.; Terraneo, G. The Halogen Bond. Chem. Rev. 2016, 116 (4), 2478-2601.

(19) Haukka, M.; Hirva, P.; Rissanen, K. Dihalogens as Halogen Bond Donors. In Non-covalent Interactions in the Synthesis and Design of New Compounds; Maharramov, A. M., Mahmudov, K. T., Kopylovich, M. N., Pombeiro, A. J. L., Eds.; Wiley: 2016; pp 187197.

(20) Kilah, N. L.; Wise, M. D.; Serpell, C. J.; Thompson, A. L.; White, N. G.; Christensen, K. E.; Beer, P. D. Enhancement of Anion Recognition Exhibited by a Halogen-Bonding Rotaxane Host System. J. Am. Chem. Soc. 2010, 132 (34), 11893-11895.

(21) Chudzinski, M. G.; McClary, C. A.; Taylor, M. S. Anion Receptors Composed of Hydrogen- and Halogen-Bond Donor Groups: Modulating Selectivity With Combinations of Distinct Noncovalent Interactions. J. Am. Chem. Soc. 2011, 133 (27), 10559-10567.

(22) Zapata, F.; Caballero, A.; Molina, P.; Alkorta, I.; Elguero, J. Open Bis(triazolium) Structural Motifs as a Benchmark To Study Combined Hydrogen- and Halogen-Bonding Interactions in Oxoanion Recognition Processes. J. Org. Chem. 2014, 79 (15), 69596969.

(23) Sarwar, M. G.; Dragisic, B.; Sagoo, S.; Taylor, M. S. A Tridentate Halogen-Bonding Receptor for Tight Binding of Halide Anions. Angew. Chem., Int. Ed. 2010, 49 (9), 1674-1677.

(24) Caballero, A.; White, N. G.; Beer, P. D. A Bidentate HalogenBonding Bromoimidazoliophane Receptor for Bromide Ion Recognition in Aqueous Media. Angew. Chem., Int. Ed. 2011, 50 (8), 18451848.

(25) Zapata, F.; Caballero, A.; White, N. G.; Claridge, T. D. W.; Costa, P. J.; Félix, V.; Beer, P. D. Fluorescent Charge-Assisted Halogen-Bonding Macrocyclic Halo-Imidazolium Receptors for Anion Recognition and Sensing in Aqueous Media. J. Am. Chem. Soc. 2012, 134 (28), 11533-11541.

(26) Lim, J. Y. C.; Marques, I.; Ferreira, L.; Félix, V.; Beer, P. D. Enhancing the Enantioselective Recognition and Sensing of Chiral Anions by Halogen Bonding. Chem. Commun. 2016, 52 (32), 55275530.

(27) Bolton, O.; Lee, K.; Kim, H.-J.; Lin, K. Y.; Kim, J. Activating Efficient Phosphorescence from Purely Organic Materials by Crystal Design. Nat. Chem. 2011, 3 (3), 205-210.

(28) Yan, D.; Delori, A.; Lloyd, G. O.; Friščić, T.; Day, G. M.; Jones, W.; Lu, J.; Wei, M.; Evans, D. G.; Duan, X. A Cocrystal Strategy to Tune the Luminescent Properties of Stilbene-Type Organic SolidState Materials. Angew. Chem., Int. Ed. 2011, 50 (52), 12483-12486.

(29) Yan, D.; Bučar, D.-K.; Delori, A.; Patel, B.; Lloyd, G. O.; Jones, W.; Duan, X. Ultrasound-Assisted Construction of Halogen-Bonded Nanosized Cocrystals That Exhibit Thermosensitive Luminescence. Chem. - Eur. J. 2013, 19 (25), 8213-8219.

(30) Kwon, M. S.; Lee, D.; Seo, S.; Jung, J.; Kim, J. Tailoring Intermolecular Interactions for Efficient Room-Temperature Phosphorescence from Purely Organic Materials in Amorphous Polymer Matrices. Angew. Chem., Int. Ed. 2014, 53 (42), 11177-11181.

(31) Schindler, S.; Huber, S. M. Halogen Bonds in Organic Synthesis and Organocatalysis. In Halogen Bonding II. Topics in Current Chemistry; Metrangolo, P., Resnati, G., Eds.; Springer: Cham, Switzerland, 2014; pp 167-203.

(32) Tamilselvi, A.; Mugesh, G. Interaction of Heterocyclic Thiols/ thiones Eliminated from Cephalosporins with Iodine and Its Biological Implications. Bioorg. Med. Chem. Lett. 2010, 20 (12), 3692-3697.

(33) Scholfield, M. R.; Vander Zanden, C. M.; Carter, M.; Ho, P. S. Halogen Bonding (X-Bonding): A Biological Perspective. Protein Sci. 2013, 22 (2), 139-152.

(34) Wilcken, R.; Zimmermann, M. O.; Lange, A.; Joerger, A. C.; Boeckler, F. M. Principles and Applications of Halogen Bonding in
Medicinal Chemistry and Chemical Biology. J. Med. Chem. 2013, 56 (4), 1363-1388.

(35) Xu, Z.; Yang, Z.; Liu, Y.; Lu, Y.; Chen, K.; Zhu, W. Halogen Bond: Its Role beyond Drug-Target Binding Affinity for Drug Discovery and Development. J. Chem. Inf. Model. 2014, 54 (1), 6978.

(36) Ford, M. C.; Ho, P. S. Computational Tools To Model Halogen Bonds in Medicinal Chemistry. J. Med. Chem. 2016, 59 (5), $1655-1670$.

(37) Lu, Y.; Shi, T.; Wang, Y.; Yang, H.; Yan, X.; Luo, X.; Jiang, H.; Zhu, W. Halogen Bonding - A Novel Interaction for Rational Drug Design? J. Med. Chem. 2009, 52 (9), 2854-2862.

(38) Carlsson, A.-C. C.; Veiga, A. X.; Erdélyi, M. Halogen Bonding in Solution. In Halogen Bonding II. Topics in Current Chemistry; Metrangolo, P., Resnati, G., Eds.; Springer: Cham, Switzerland, 2014; pp 49-76.

(39) Bedin, M.; Karim, A.; Reitti, M.; Carlsson, A.-C. C.; Topić, F.; Cetina, M.; Pan, F.; Havel, V.; Al-Ameri, F.; Sindelar, V.; Rissanen, K.; Gräfenstein, J.; Erdelyi, M. Counterion Influence on the N-I-N Halogen Bond. Chem. Sci. 2015, 6 (7), 3746-3756.

(40) Koskinen, L.; Hirva, P.; Kalenius, E.; Jääskeläinen, S.; Rissanen, K.; Haukka, M. Halogen Bonds with Coordinative Nature: Halogen Bonding in a $\mathrm{S}-\mathrm{I}^{+}-\mathrm{S}$ Iodonium Complex. CrystEngComm 2015, 17 (6), 1231-1236.

(41) Turunen, L.; Warzok, U.; Puttreddy, R.; Beyeh, N. K.; Schalley, C. A.; Rissanen, K. $\left[\mathrm{N} \cdots \mathrm{I}^{+} \cdots \mathrm{N}\right]$ Halogen-Bonded Dimeric Capsules from Tetrakis(3-Pyridyl)ethylene Cavitands. Angew. Chem., Int. Ed. 2016, 55 (45), 14033-14036.

(42) Turunen, L.; Peuronen, A.; Forsblom, S.; Kalenius, E.; Lahtinen, M.; Rissanen, K. Tetrameric and Dimeric $\left[\mathrm{N} \cdots \mathrm{I}^{+} \cdots \mathrm{N}\right]$ Halogen-Bonded Supramolecular Cages. Chem. - Eur. J. 2017, 23 (48), 11714-11718.

(43) Carlsson, A.-C. C.; Mehmeti, K.; Uhrbom, M.; Karim, A.; Bedin, M.; Puttreddy, R.; Kleinmaier, R.; Neverov, A. A.; Nekoueishahraki, B.; Gräfenstein, J.; et al. Substituent Effects on the $[\mathrm{N}-\mathrm{I}-\mathrm{N}]^{+}$Halogen Bond. J. Am. Chem. Soc. 2016, 138 (31), 9853-9863.

(44) Desiraju, G. R.; Shing Ho, P.; Kloo, L.; Legon, A. C.; Marquardt, R.; Metrangolo, P.; Politzer, P.; Resnati, G.; Rissanen, K. Definition of the Halogen Bond (IUPAC Recommendations 2013)*. Pure Appl. Chem. 2013, 85 (8), 1711-1713.

(45) Sarwar, M. G.; Dragisic, B.; Salsberg, L. J.; Gouliaras, C.; Taylor, M. S. Thermodynamics of Halogen Bonding in Solution: Substituent, Structural, and Solvent Effects. J. Am. Chem. Soc. 2010, 132 (5), 1646-1653.

(46) Grabowski, S. J. Hydrogen and Halogen Bonds Are Ruled by the Same Mechanisms. Phys. Chem. Chem. Phys. 2013, 15 (19), $7249-7259$

(47) Metrangolo, P.; Meyer, F.; Pilati, T.; Resnati, G.; Terraneo, G. Halogen Bonding in Supramolecular Chemistry. Angew. Chem., Int. Ed. 2008, 47 (33), 6114-6127.

(48) Hassel, O.; Hope, H. Structure of the Solid Compound Formed by Addition of Two Molecules of Iodine to One Molecule of Pyridine. Acta Chem. Scand. 1961, 15, 407-416.

(49) Hakkert, S. B.; Erdélyi, M. Halogen Bond Symmetry: The N-XN Bond. J. Phys. Org. Chem. 2015, 28 (3), 226-233.

(50) Meazza, L.; Martí-Rujas, J.; Terraneo, G.; Castiglioni, C.; Milani, A.; Pilati, T.; Metrangolo, P.; Resnati, G. Solid-State Synthesis of Mixed Trihalides via Reversible Absorption of Dihalogens by Non Porous Onium Salts. CrystEngComm 2011, 13 (13), 4427-4435.

(51) Lin, J.; Martí-Rujas, J.; Metrangolo, P.; Pilati, T.; Radice, S.; Resnati, G.; Terraneo, G. Solution and Solid State Synthesis of the Discrete Polyiodide $\mathrm{I}_{7}{ }^{3-}$ under Modular Cation Templation. Cryst. Growth Des. 2012, 12 (11), 5757-5762.

(52) Martí-Rujas, J.; Meazza, L.; Lim, G. K.; Terraneo, G.; Pilati, T.; Harris, K. D. M.; Metrangolo, P.; Resnati, G. An Adaptable and Dynamically Porous Organic Salt Traps Unique Tetrahalide Dianions. Angew. Chem., Int. Ed. 2013, 52 (50), 13444-13448. 
(53) Yushina, I. D.; Kolesov, B. A.; Bartashevich, E. V. Raman Spectroscopy Study of New Thia- and Oxazinoquinolinium Triodides. New J. Chem. 2015, 39 (8), 6163-6170.

(54) Bartashevich, E.; Troitskaya, E.; Tsirelson, V. Understanding the Bifurcated Halogen Bonding N $\cdots \mathrm{Hal} \cdots \mathrm{N}$ in Bidentate Diazaheterocyclic Compounds. Comput. Theor. Chem. 2015, 1053, 229-237.

(55) Bartashevich, E. V.; Yushina, I. D.; Stash, A. I.; Tsirelson, V. G. Halogen Bonding and Other Iodine Interactions in Crystals of Dihydrothiazolo(oxazino)quinolinium Oligoiodides from the Electron-Density Viewpoint. Cryst. Growth Des. 2014, 14 (11), 56745684.

(56) Bartashevich, E. V.; Matveychuk, Y. V.; Troitskaya, E. A.; Tsirelson, V. G. Characterizing the Multiple Non-Covalent Interactions in N, S-Heterocycles-diiodine Complexes with Focus on Halogen Bonding. Comput. Theor. Chem. 2014, 1037, 53-62.

(57) Bartashevich, E. V.; Troitskaya, E. A.; Tsirelson, V. G. The N...I Halogen Bond in Substituted Pyridines as Viewed by the Source Function and Delocalization Indices. Chem. Phys. Lett. 2014, 601, 144-148.

(58) Ding, X.; Tuikka, M. J.; Hirva, P.; Kukushkin, V. Y.; Novikov, A. S.; Haukka, M. Fine-Tuning Halogen Bonding Properties of Diiodine through Halogen-halogen Charge Transfer - Extended $\left[\mathrm{Ru}\left(2,2^{\prime}\right.\right.$-bipyridine $\left.)(\mathrm{CO})_{2} \mathrm{X}_{2}\right] \cdot \mathrm{I}_{2}$ Systems $(\mathrm{X}=\mathrm{Cl}, \mathrm{Br}, \mathrm{I})$. CrystEngComm 2016, 18 (11), 1987-1995.

(59) CrysAlis PRO; Agilent Technologies Ltd: Yarnton, Oxfordshire, England, 2014.

(60) Dolomanov, O. V.; Bourhis, L. J.; Gildea, R. J.; Howard, J. A. K.; Puschmann, H. OLEX2: A Complete Structure Solution, Refinement and Analysis Program. J. Appl. Crystallogr. 2009, 42 (2), 339-341.

(61) Sheldrick, G. M. Crystal Structure Refinement with SHELXL. Acta Crystallogr., Sect. C: Struct. Chem. 2015, C71 (1), 3-8.

(62) Reiss, G. J.; Leske, P. B. The Twinned Crystal Structure of bis((4-Aminopyridin-1-Ium) Iodide Triiodide, $\mathrm{C}_{20} \mathrm{H}_{28} \mathrm{I}_{8} \mathrm{~N}_{8}$. Z. Kristallogr. NCS 2014, 229 (4), 452-454.

(63) Brayer, G. D.; James, M. N. G A charge-transfer complex: bis(2,4,6-trimethyl-1-pyridyl)iodonium perchlorate. Acta Crystallogr., Sect. B: Struct. Crystallogr. Cryst. Chem. 1982, B38, 654-657.

(64) Okitsu, T.; Yumitate, S.; Sato, K.; In, Y.; Akimori Wada, A. Substituent Effect of Bis(pyridines)iodonium Complexes as Iodinating Reagents: Control of the Iodocyclization/Oxidation Process. Chem. - Eur. J. 2013, 19, 4992-4996.

(65) Batsanov, A. S.; Lightfoot, A. P.; Twiddle, S. J. R.; Whiting, A. Acta Crystallogr., Sect. E: Struct. Rep. Online 2006, E62, o901-o902.

(66) Georgiou, D. C.; Butler, P.; Browne, E. C.; Wilson, D. J. D.; Dutton, J. L. On the Bonding in Bis-pyridine Iodonium Cations. Aust. J. Chem. 2013, 66, 1179-1188.

(67) Lommerse, J. P. M.; Stone, A. J.; Taylor, R.; Allen, F. H. The Nature and Geometry of Intermolecular Interactions between Halogens and Oxygen or Nitrogen. J. Am. Chem. Soc. 1996, 118 (13), 3108-3116.

(68) Brammer, L.; Bruton, E. A.; Sherwood, P. Understanding the Behavior of Halogens as Hydrogen Bond Acceptors. Cryst. Growth Des. 2001, 1 (4), 277-290.

(69) Zordan, F.; Brammer, L.; Sherwood, P. Supramolecular Chemistry of Halogens: Complementary Features of Inorganic (M$\mathrm{X})$ and Organic $\left(\mathrm{C}-\mathrm{X}^{\prime}\right)$ Halogens Applied to $\mathrm{M}-\mathrm{X} \cdots \mathrm{X}^{\prime}-\mathrm{C}$ Halogen Bond Formation. J. Am. Chem. Soc. 2005, 127 (16), 5979-5989.

(70) Pauling, L. The Nature of the Chemical Bond, 3rd ed.; Cornell University Press: Ithaca, NY, 1960.

(71) Pyykkö, P.; Atsumi, M. Molecular Single-Bond Covalent Radii for Elements 1-118. Chem. - Eur. J. 2009, 15 (1), 186-197.

(72) Jones, R. H.; Knight, K. S.; Marshall, W. G.; Clews, J.; Darton, R. J.; Pyatt, D.; Coles, S. J.; Horton, P. N. Colossal Thermal Expansion and Negative Thermal Expansion in Simple Halogen Bonded Complexes. CrystEngComm 2014, 16 (2), 237-243.

(73) Batsanov, A. S.; Howard, J. A. K.; Lightfoot, A. P.; Twiddle, S. J. R.; Whiting, A. Stereoselcetive Chloro-Deboronation Reactions
Induced by Substituted Pyridine-Iodine Chloride Complexes. Eur. J. Org. Chem. 2005, 2005, 1876-1883.

(74) The purity of the $\mathrm{Br}_{2}$ starting material and the absence of, for example, significant amounts of $\mathrm{HBr}$ were subsequently confirmed by ${ }^{1} \mathrm{H}$ NMR spectroscopy. The presence of a catalytic amount of $\mathrm{HBr}$ in the reaction mixture, however, cannot be excluded.

(75) Harding, P.; Harding, D. J.; Pakawatchai, C.; Phetmung, H. Catena-Poly[[bis[-1-(2-Pyridyl)pyridinium-2-Thiolate]-2-N:S;-2S:N-dicopper(I)]-Di-Chloro]. Acta Crystallogr., Sect. E: Struct. Rep. Online 2006, E62, $\mathrm{m} 1335-\mathrm{m} 1337$.

(76) Owen, J. S.; Day, M. W.; Bercaw, J. E. CCDC 199233. CSD Commun. 2005

(77) Owen, J. S.; Labinger, J. A.; Bercaw, J. E. Pyridinium-Derived $\mathrm{N}$-Heterocyclic Carbene Complexes of Platinum: Synthesis, Structure and Ligand Substitution Kinetics. J. Am. Chem. Soc. 2004, 126 (26), $8247-8255$

(78) Piro, N. A.; Owen, J. S.; Bercaw, J. E. Pyridinium-Derived NHeterocyclic Carbene Ligands: Syntheses, Structures and Reactivity of N-(2'-Pyridyl)pyridin-2-Ylidene Complexes of nickel(II), palladium(II) and platinum(II). Polyhedron 2004, 23 (17), 2797-2804.

(79) Kinoshita, I.; James Wright, L.; Kubo, S.; Kimura, K.; Sakata, A.; Yano, T.; Miyamoto, R.; Nishioka, T.; Isobe, K. Design and Synthesis of Copper Complexes of Novel Ligands Based on the Pyridine Thiolate Group. Dalt. Trans. 2003, 0 (10), 1993-2003.

(80) Fox, B. A.; Threlfall, T. L. 2,3-diaminopyridine. Org. Synth. 2003, 44, 34-39.

(81) Lackova, D.; Ondrejkovicova, I.; Padelkova, Z.; Koman, M. Syntheses, crystal structures, and IR spectra of isonicotinamideisonicotinamidium bis(isonicotinamide)-tetrakis(isothiocyanato)ferrate(III) and isonicotinamidium chloride. J. Coord. Chem. 2014, $67,1652-1663$.

(82) Tuikka, M.; Haukka, M. Crystal Structure of the PyridineDiiodine (1/1) Adduct. Acta Cryst., Sect. E: Cryst. Commun. 2015, E71, o463-o463. 